Для цит.: Дуков Е.В., Эвалльё В.Д., Семенова Е.А., Магидович М.Л., Гуркина Н.С., Казючиц М.Ф., Вирен Д.Г., Смолев Д.Д. Образы машин и техники. Авторские интерпретации // Художественная культура. 2021. № C. 396-437. https://doi.org/10.51678/2226-0072-2021-4-396-437.

Гуркина Наталия Семеновна

Кандидат искусствоведения, доцент, Санкт-

Петербургская государственная художественно-

промышленная академия им. А.Л. Штиглица, Россия, Санкт-Петербург

ORCID ID: 0000-0001-5949-8745

nsgurkina@gmail.com

\section{Казючиц Максим Федорович}

Кандидат философских наук, доцент, профессор,

кафедра сценарного мастерства, Академия

кафедра сценарного мастерства, Акад

Государственный центральный музей кино, Россия, Москва

ORCID ID: 0000-0002-3015-3046

mkazuchitz@gmail.com

Вирен Денис Георгиевич

Кандидат философских наук, заведующий сектором современного искусства Запада, Государственный институт искусствознания, Россия, Москва ORCID ID: 0000-0002-3680-6028 ORCID ID: 0000-0002

\section{Смолев Даниил Дмитриевич}

Кандидат философских наук, старший научный сотрудник, сектор современного искусства Запада, Государственный институт искусствознания, Россия Москва

ORCID: 0000-0002-4944-8792

danilasmolev@mail.ru

Ключевые слова: искусство, экранная культура эстетика, машинная цивилизация, технология, киберпространство, новые медиа, человек, техноарт, фотография, инсталляция, кинематограф, цирк.
For cit.: Dukov E.V., Evallyo V.D., Semenova E.A., Magidovich M.L., Gurkina N.S. Kazyuchits M.F., Viren D.G., Smolev D.D. Images of Machines and Technology. Author's Interpretations. Hudozhestvennaya kul'tura [Art \& Culture Studies] 2021, no. 4, pp. 396-437. https://doi.org/10.51678/2226-0072-2021-4-396-437. (In Russian)

Дуков Е.В., Эвалльё В.Д., Семенова Е.А., Магидович М.Л., Гуркина Н.С., Казючиц М.Ф., Вирен Д.Г., Смолев Д.Д.

\section{Образы машин и техники. Авторские интерпретации}

\author{
Проблема взаимодействия машинного и человеческого была актуальна во все времена \\ развития цивилизации. Наиболее остро этот вопрос встал в эпоху научно-технического \\ прогресса, создав широкое проблемное поле. В данной дискуссии исследователи поста- \\ рались с разных сторон подойти к уже сложившейся ситуации повсеместного внедрения \\ новых технологий, машин в сферу искусства, породившей и необходимость авторских \\ интерпретаций соотношения технологического и гуманистического, начиная с постанов- \\ ки проблемы идентификации и очерчивания границ человеческого «я» в эпоху компьюте- \\ ризации многих сфер бытия. Авторы обратились к теме репрезентации образов техники \\ в киноискусстве, индустриализации в американском искусстве первой половины XX века, \\ в современных инсталляциях А. Райхштейна, сценическом пространстве, в облике города \\ и виртуальной среде (на примере популярной платформы TikTok). Авторы приходят \\ к выводам, что образы машин и технических устройств могут быть связаны с темой про- \\ изведения, образовывать контекст, декоращию, фигурировать в роли формального приема

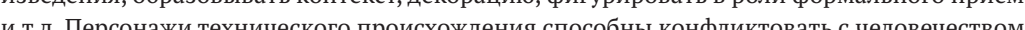 \\ и т.д. Персонани тех иес
}


Dukov Evgeny V.

Doctor of Philosophy, PhD in Art History, Professor, Chief Researcher, Mass Media Arts Department, State Institut for Art Studies, Russia, Moscow

ORCID ID: 0000-0002-2097-369X

edukov@rambler.ru

\section{Evallyo Violetta D.}

$\mathrm{PhD}$ in Cultural Studies, Senior Researcher, Mass Media Arts Department, State Institute for Art Studies, Russia Moscow

ORCID ID: 0000-0002-4531-4922

amaris_evally@mail.ru

\section{Semenova Elena A.}

$\mathrm{PhD}$ in Pedagogic, Senior Researcher, Laboratory of Literature and Theater, Institute of Art Education and Cultural Studies of the Russian Academy of Education,

Russia, Moscow

ORCID ID: 0000-0002-1316-3162

semenova05@list.ru

\section{Magidovich Marina L.}

Doctor of Sociological Sciences, PhD in Art History Professor, A.I. Herzen Russian State Pedagogical

University, Russia, St. Petersburg

ORCID ID: 0000-0003-0747-1078

maguidov@mail.ru

\section{Gurkina Natalia S.}

PhD in Art Studies, Associate Professor, Saint Petersburg Stieglitz State Academy of Art and Design, Russia, St. Petersburg

ORCID ID: 0000-0001-5949-8745

nsgurkina@gmail.com

\section{Kazyuchits Maksim F.}

PhD in Philosophy, Associated Professor, Academy of Media Industry; Researcher, State Central Film Museum, Russia, Moscow

(D) 000-0002-3015-3046

mkazuchitz@gmail.com

\section{Viren Denis G.}

$\mathrm{PhD}$ in Philosophy, Head of the Contemporary Western Art Department, State Institute for Art Studies, Russia,

Moscow

ORCID ID: 0000-0002-3680-6028

denis.viren@gmail.com

\section{Smolev Daniil D.}

$\mathrm{PhD}$ in Philosophy, Senior Researcher, Contemporary Western Art Department, State Institute for Art Studies, Russia, Moscow

ORCID: 0000-0002-4944-8792

danilasmolev@mail.ru

Keywords: art, screen culture, aesthetics, machine civilization, technology, cyberspace, new media, man techno-art photo

\section{Dukov Evgeny V., Evallyo Violetta D., Semenova Elena A., Magidovich Marina L., Gurkina Natalia S.,} Kazyuchits Maksim F., Viren Denis G., Smolev Daniil D.

Images of Machines and Technology. Author's Interpretations

The problem of interaction between machines and humans has been relevant at all times of human civilization's development. This subject arose most acutely in the era of scientific and technical progress, giving rise to a wide problem field, many aspects of which still require scientific understanding. In this discussion, the researchers tried to analyze the situation of the widespread implantation of new technologies and machines into the art field. The integration of technology generates the necessity of the author's interpretations about the relationship between the technological and the humanistic. The authors turned to the problem of identification and draw the boundaries of the human " $I$ " in the era of computerization of many spheres of life, to the topic of technology's images in cinema (Polish, American, documentary), to the image of industrialization in American art of the first half of the 20th century, to modern installations by A. Reichstein, to the screen media in the stage space, in the city, and even in the virtual environment (for example on incredibly popular TikTok platform). The authors conclude that machine civilization is closely intertwined with humans. The images of technology are overgrown with countless interpretations: they can act as a theme, device, context, decoration, character, conflict with humanity, fight for its prosperity, try to identify itself in the human world. 
Дуков Е.В., Эвалльё В.Д.

\section{Идентичность в зеркале экранных медиа}

На протяжении XX века человек и компьютер быстро «врастали» друг в друга. Компьютер, кажется, призван быть для человека одним из главных факторов индивидуального познания окружающего мира и самого себя. Он может быть своеобразным волшебным кристаллом, который подгоняется в процессе жизнедеятельности под уникальные параметры индивида и меняется вместе с ним. Но имеем ли мы дело с индивидом, играющим с компьютером-кристаллом, или с кем-то другим?

С рубежа 1950-1960 годов, когда Э. Эриксон в исследовании «Детство и общества» (1950) и позже, в книге «Идентичность и жизненный цикл» (1959) сформулировал теорию психосоциального подхода, термин «идентичность» оказался в центре острых дискуссий в разных гуманитарных науках. Примерно в то же время французский философ М. Мерло-Понти попытался нарисовать картину возникновения идентичности. Он констатировал: «...я - не перед моим телом, я в моем теле или, точнее, я есть мое тело» [9, с. 200]. Однако понятие идентичности неразделимо связано с интеллектуальным познанием не только самого себя, но и своей интегрированности в объективное пространство. И.А. Бескова пишет: «Интеллект проявляется в способности движения и взаимодействия с реальным миром» [1, с. 26]. Где сегодня проходит водораздел между окружающей средой и индивидом, насколько он устойчив? От того, включены домашние экраны (телевизор или монитор) или выключены, доступна сеть или нет, зависит качество и границы окружающей человека среды. Британский социолог Д. Урри не случайно подчеркивал: «К концу XX века интернет стал метафорой социальной жизни как текучей среды. <...> Появляются все новые и новые компьютерные сети и связи. В этом текучем пространстве невозможны раз и навсегда определенные идентичности, поскольку текучий мир - это мир смесей» [19, с. 64]. Квантовый мир?

Вот эти новые «игры» заставляют, в частности, по-новому рассмотреть процесс функционирования искусства, поставив в центр нового человека, новые способы его контактов с окружающим информационным полем и искусственным интеллектом [см.: 3].

Вопрос идентичности, поднятый Е.В. Дуковым выше (и в его более ранних докладах и публикациях), бесспорно, является актуальным и по сей день. Однако поставим и такой вопрос: если отстраниться от человеческой потребности разграничить себя, свое сознание и окружающую среду, то можно ли подобные категории применить и в отношении объективного мира? Насколько реальным является виртуальное пространство города, с мельчайшими подробностями перенесенное в цифру, да еще и дополненное информационными блоками, маршрутами? Безусловно, с точки зрения удобства современные технологии необычайно дружелюбны. Например, структурное и функциональное наполнение различных экранных поверхностей в московском метрополитене [20] или обновленные функции Googleкарт не только позволяют проложить маршрут из местоположения до требуемого адреса, но и снабжены довольно чувствительными инструментами геолокации. Стоит сделать шаг, как приложение мгновенно корректирует направление, предупреждая, если плохо ориентирующийся в географических координатах индивид сделает этот самый шаг в противоположном маршруту направлении.

Ультрасовременные технологии таким образом снимают необходимость вылавливать прохожих, способных указать верное направление, нужную остановку или номер автобуса. «Язык до Киева доведет» - больше не единственный способ куда-то попасть, уточнение географического положения нужных объектов в диапазоне 2-5 метров и более маленьких дистанций посредством человеческого общения - необязательно, ведь есть дружелюбное приложение, упрощающее выполнение задачи передвижения в пространстве, снимающее стресс лихорадочного выбора в толпе лица, способного оказать потерявшемуся «информационную поддержку».

Г.Л. Тульчинский пишет: «с конца XIX - начала XX века отношения человека и машины стали одной из главных, если не центральной проблемой искусства. С одной стороны - пафос новых горизонтов восприятия не только микромира и дальнего космоса, но и обыденного опыта, в духе „киноглаза“ Дзиги Вертова, которому доступна реальность, недоступная человеческому глазу. Это накладывалось на пафос создания нового общества, формирования нового „улучшенно- 


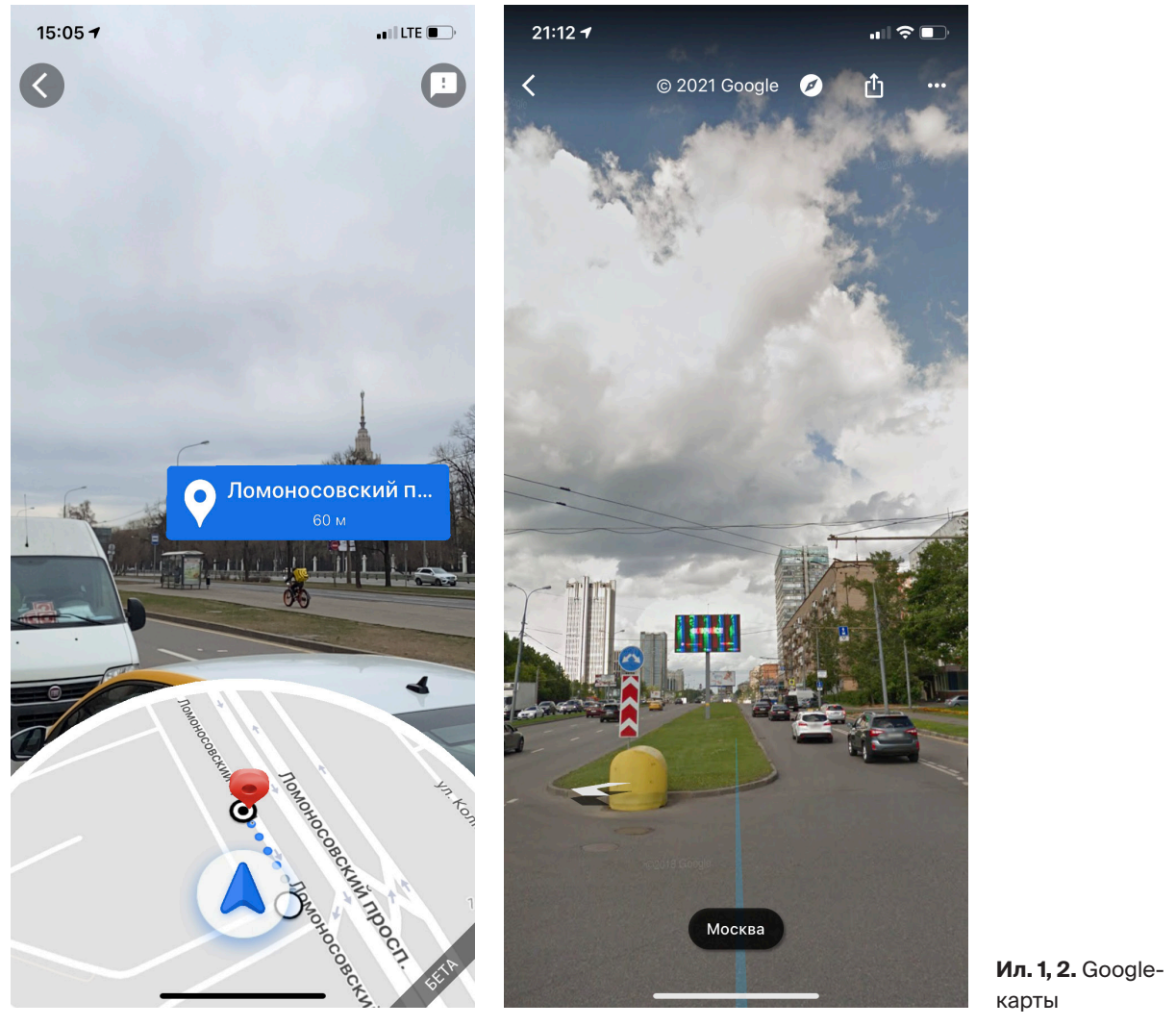

го“ человека» [18, с. 115]. И, возвращаясь к нашему вопросу, - не являются ли технологии цифровой, дополненной реальности своеобразной попыткой «улучшить» город, сделав его еще более адаптированным под нужды горожанина, сжав его до размеров экранного устройства, буквально умещая пространство на ладони и лишая его тем самым идентичности?

Во многом похожая ситуация наблюдается в виртуальных экспозициях музейных институций. Как мы писали ранее, «можно констатировать очередную волну десакрализации - и самой институции музея, „храма искусства“, и музейного художественного экспоната» [21, с. 240]. То есть частичную утрату идентичности, тождественности архитектурного ансамбля самого музея, его уникальной ауры и ау- тентичности. Возвращаясь к теме города, участь которого, как мы обозначили, во многом соотносится с судьбой музеев, обратимся к выводу, сделанному И. Хельцлем: «цифровые экраны являются частью пространства общей реальности (spatium communis) „дополненного города“, состоящего из построенной и виртуальной архитектуры, электронной и беспроводной инфраструктуры, в которой изображения и граждане-пользователи циркулируют и коммуницируют» [24, p. 475].

Таким образом, будь то городское или музейное пространство, оно вынуждено подчиняться требованиям современности - иметь и материальное, и виртуальное воплощения, дополняющие, комментирующие друг друга. При непосредственном посещении выставок внедренные в материальную действительность экранные панели и метки для активации дополненной реальности - имеют все же вторичное, вспомогательное и необязательное значение, в то время как в пространстве спектаклей экраны все чаще плотно интегрированы в художественную материю.

Вслед за музейными институциями, активно внедряющими в экспозиционные среды новые технологии и развивающими свое цифровое воплощение в Сети, цирки поддаются веяниям современности и начинают включать экранные поверхности непосредственно в сценическое пространство. В данном тексте мы обращаемся к спектаклю «По щучьему велению», показанному в Большом Московском цирке в марте 2021 года.

Условно все экранные поверхности в спектакле можно разделить на четыре регистра по пространственному расположению и степени интегрированности в художественную реальность. Однако с точки зрения их смыслового месседжа мы разграничим их на два типа, один из которых содержит в своей структуре три разноуровневые плоскости. Наибольший объем пространства занимают панорамные панели по периметру зала, расположенные таким образом, что визуально разграничивают зрительские места и купол. Эта экранная полоса реализуется технологией видеостены - то есть изображения на соседствующих панелях продолжают транслируемую панораму.

Вторая зона - экраны, установленные в области выхода из зрительского зала. Сразу отметим, они не привлекают особого внимания в силу того, что демонстрируемые на их поверхности изображения плотно интегрированы в общую транслируемую картину. Однако осо- 


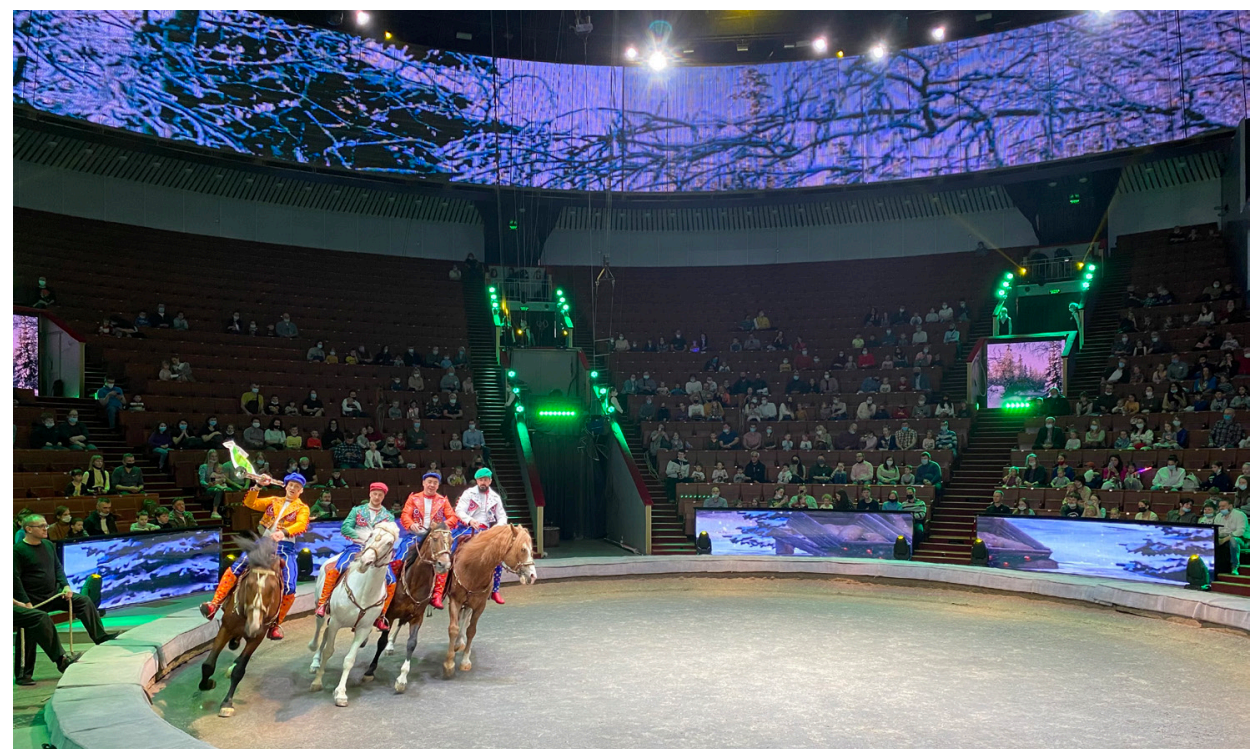

Ил. 3. «По щучьему велению». Большой Московский цирк. Март 2021

бенность этого типа экранов в том, что он тесно связан с центральной областью, о которой скажем чуть позже.

Нижний экранный ряд расположен перед первыми зрительскими рядами по одному на каждый сектор. Большую часть времени все три типа экранных поверхностей синхронизированы - демонстрируют фрагменты единой экранной «реальности». Однако по контенту они являются технологичными декорациями самого спектакля и визуализируют среду, в которую попадают персонажи, будь это зимний лес, городская площадь или царский терем. Помимо функции пространственных якорей эти экраны реализуют и темпо-ритмическую составляющую спектакля: в сценах движения Емели на своей печи транслируются природные виды, имитирующие вид «из окошка» при лихой езде, усиливая общую динамику.

Примечательно, что эти три типа экранных поверхностей буквально продолжают и дорисовывают трехмерную модель художественной реальности снизу вверх: нижние соотносятся с линией земли, средние (в зоне выхода) - примерно на уровне глаз, а панорамная полоса выше. Таким образом, пространство циркового зрелища оказывается зажатым между землей и небом, запертым в полусфере, создавая иллюзию иммерсивного спектакля, в условиях которого зрители буквально запираются внутри художественной реальности.

Центральная экранная поверхность расположена над выходом для артистов. Она самая большая и, с одной стороны, образует задник декорации для время от времени разворачивающейся там истории, или же включается в общий визуальный ряд, транслируемый панорамными панелями. Однако эта экранная поверхность смонтирована с соседними, чуть наклоненными в сторону сцены, не встык, а строго перпендикулярно линии горизонта. Эта зона дополнена тремя экранами поменьше, расположенными ниже, что позволяет расценивать ее второй по значимости после непосредственно сцены. Одна панель чуть выставлена вперед, в то время как две более маленькие чуть поодаль, вместе они образуют подобие створок триптиха. Эти три экранные панели связаны с центральными у выходов и так же занимают пространство между небом и землей - зоной обитания персонажей спектакля.

Функционально эта зона позволяет перенести внимание зрителя со сцены, на которой происходит смена декораций, но при этом не прерывать целостность сюжета. Пространственно эта область чаще всего выступает в роли царского терема, а на экранах транслируются декорации, в которых живут царствующие особы.

Когда внимание зрителя полностью переключается с пространства сцены, центральная панель панорамного блока иногда становится зоной трансляции отдаленных от персонажей мест, создавая иллюзию полиэкрана, - происходит своего рода монтаж разнопространственных локусов в границах единой освещенной зоны. Например, в сцене наблюдения царевной в подзорную трубу за звездами или далекими островами. Важно, что эти зоны становятся акцентами в смеховой составляющей зрелища, будь то оказавшийся в шапке-ушанке на острове «шоколадный заяц» Пьер Нарцисс или подводное царство Шуки, глазами которой зрители увидели искаженное в воде лицо Емели, сунувшего голову в прорубь на противоположной стороне цирковой полусферы.

Суммируем, что экраны в пространстве цирка позволяют сместить центр зрелища с арены, расширить его до фактических материальных границ полусферы, вмещающей в себя и сцену, и зрительный зал, 


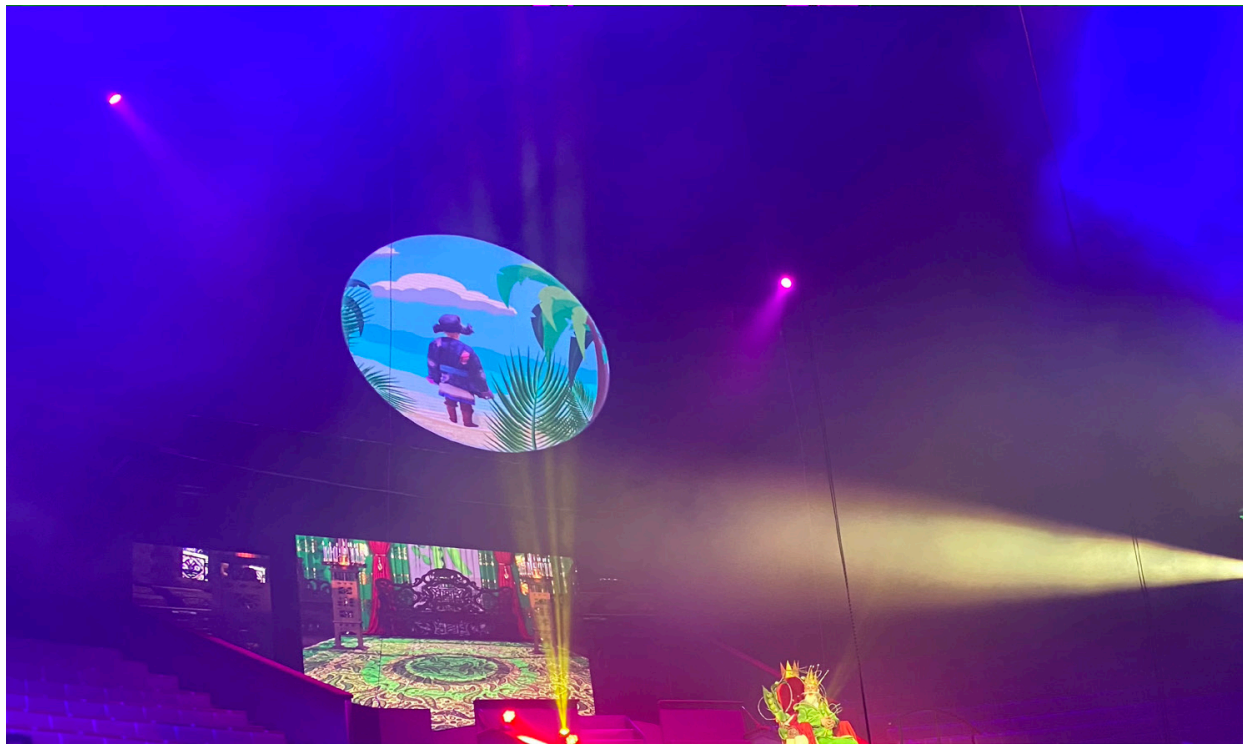

Ил. 4. «По щучьему велению». Большой Московский цирк. Март 2021

и проходы. Так образуются вертикальные и горизонтальные элементы каркаса пространства зрелища, надстраивая над художественной реальностью спектакля еще и пространственный аттракцион. Из этого следует, что использование экранных технологий в цирке бывает идентично функциям экранов в музейной среде и, шире, - городском пространстве. И чаще всего это именно коммуникативная функция, связывающая между собой различные пласты реальностей.

Семенова Е.А.

\section{Ультрасовременные «машины смеха»}

В пандемию Covid-19 общество испытало «экзистенциальный кризис», ощутив, что «жизнь и творчество в любой момент могут быть прерваны смертью» [13, с. 317]. Возникла острая потребность почувствовать сопричастность к социуму. К началу пандемии машины, посредством которых могло бы осуществляться общение людей друг с другом, были уже способны обеспечить человеку присутствие «бравых товарищей и призраков, с которыми болтаешь и смеешься, когда есть охота болтать и смеяться, и которых посылаешь к черту, когда они становятся скучными, - как возмещение недостающих друзей» $[10$, с. $15-16]$.

Исследователи пришли к выводу, что несложно «научить машину порождать то, что может показаться человеку смешным... <...> [сложнее обучить] понимать и оценивать юмор» [7, с. 216]. Но и эта задача во многом была решена к началу 2020 года.

В качестве ультрасовременной «машины», обеспечивающей юмористическую коммуникацию во время пандемии, мы рассмотрели китайское приложение TikTok, запущенное в 2016 году. В 2020 году TikTok поставил рекорд по количеству созданных с помощью него комических видеороликов, мемов, флешмобов на тему коронавируса не профессиональными артистами, юмористами, стендап-комиками, а рядовыми пользователями. «TikTok - это приложение, которое по функционалу совмещает в себе популярные во всем мире Instagram и Snapchat. Основной задачей в этой социальной сети является - coздание видеороликов» [2, с. 574] длительностью от 3 до 60 секунд [22; 28, p. 11]. Если в 2018 году данное приложение занимало седьмое место среди самых популярных в мире, то уже в 2019 году ему пророчили первенство среди других приложений. В чем же заключается секрет его популярности, если TikTok предлагает тот же набор фильтров для мобильной фото- и видеокамеры, звуковых и визуальных комических эффектов, что и многие другие мобильные приложения?

Как отмечают исследователи, TikTok-блогеры и простые TikTok-пользователи, причина народной любви к этому приложению состоит в том, что оно предоставляет широкие возможности человеку не только проявлять собственное творчество, в частности юмористическое, но и получать на него обратную реакцию. Разработчики этого приложения более внимательны к системе распознавания в TikTok реакций пользователей на контент [2, с. 574], успешно решают сложную задачу прогнозировать, просчитывать человеческую смеховую реакцию, отличать юмористическое сообщение от серьезного.

Наблюдая за жизнью TikTok, можно заметить, что его аудитории менее интересны юмористические программы и шоу, в которых им «диктуют <...>, когда и где <...> смеяться» [4, с. 103]. Вследствие того, что изначально TikTok создавался как музыкальное приложение, в нем 


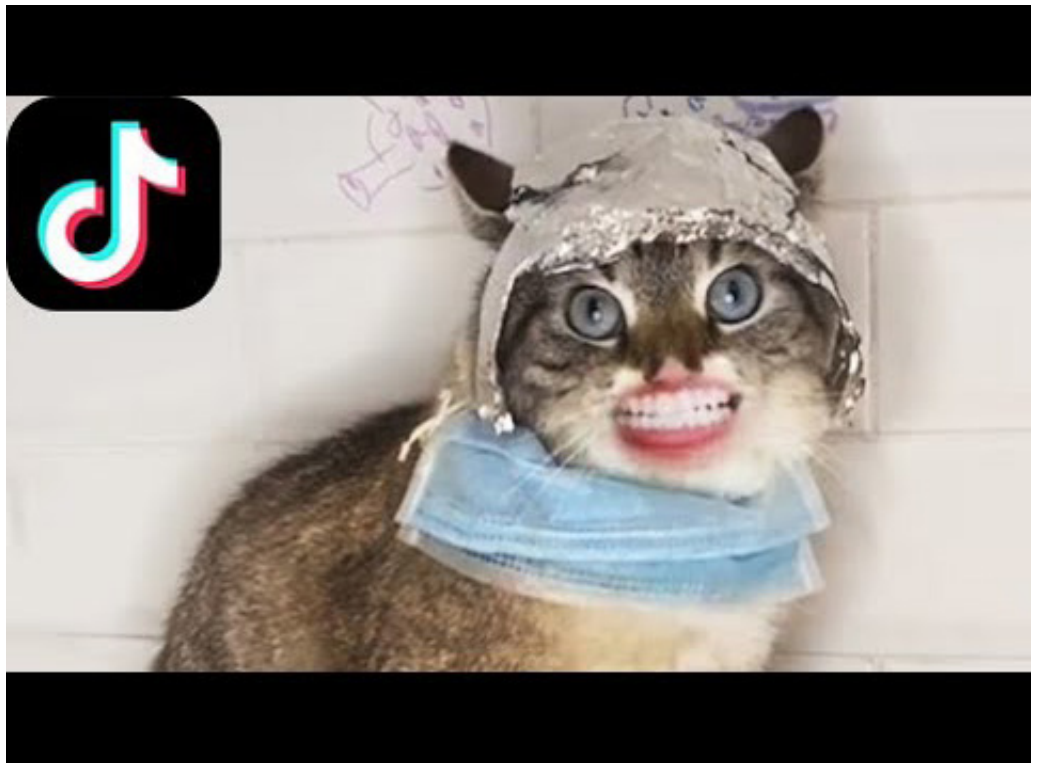

Ил. 5. Говорящий кот в TikTok рассуждает о коронавирусе голосом блогера Александра Дмитриенко цию; коты в медицинских масках; коты, выясняющие друг с другом семейные отношения и т.д. Основой для многих комических вариативных сюжетов о выздоровлении от Covid-19 стала фраза Александра Дмитриенко «Это оно», очень часто завершающая видеоролик на тему выздоровления от Covid-19, в котором к человеку возвращается обоняние. Во всех каламбурах и шутках в TikTok про пандемию важно то, что «TikTok Covid» является отражением пандемии в зеркалах комнаты смеха, не имеющим точного сходства с пандемией реальной.

Безусловно, можно считать, что TikTok не достоин нашего внимания. Однако вспомним, что такое же предвзятое отношение наблюдалось в Европе в начале XX века к совсем еще юной «кинокомической», завоевавшей любовь миллионов людей земного шара. Действительно, многие кумиры TikTok мало читают книг, но не потому, что не умеют читать, а потому что «нет гэгов в книгах» [16, с. 78]. В этом, по сути, TikTok во многом повторяет развитие «кинокомической машины». Он демократичен, сближает людей различного возраста и социального статуса тем же, чем объединяли людей немые кинокомедии и средневековый карнавал - желанием играть в несерьезные игры и вовлекать в них других.

Главная задача юмористических видео-, фото-, аудиоредакторов TikTok заключается в том, чтобы не помочь, а буквально принудительно «заставить человека рассмеяться -<...> войти с ним в эмоциональный контакт» [16, с. 286].

Социальную сеть TikTok в период пандемии можно сравнить c «зеркальными госпиталями», распространенными в средневековой Европе, в которых цель лечения заключалась в достижении изменения у пациента отношения к болезни. Подобные техники лечения использовались в TikTok- челленджах, посвященных пандемии Covid-19.

В 2020 году карнавальное мировосприятие стало жизненно необходимым, вследствие чего на первый план вышло народное юмористическое творчество, вытеснив техничное, профессиональное искусство юмористов и комиков. Все получили равные права на карнавализацию действительности, миссия которой - выработка морально-нравственного иммунитета к унынию и страху.

Парадоксально, но приходится признать, что «машины смеха» способны в критический момент помочь человеку проявить свое искусство быстрого реагирования. разговаривают коты, сидящие в холодильниках и задающие вопрос: «Подсказать что-то, женщина? Нужна подсказка?»; коты, требующие окружающих соблюдать по отношению к ним двухметровую дистангер Александр Дмитриенко. Одна его фраза быстро подхватывается другими пользователями, становясь не только TikTok-хитом, но основой чужого юмористического творчества. Говорящие коты, очень популярные в TikTok, практически все говорят голосом Александра Дмитриенко (он же Шура Стоун и Похититель Ароматов). Его голосом 
Магидович М.л.

\section{Мнимые объекты аудиовизуальных инсталляций Александра}

\section{Райхштейна}

Обманки никого не обманывали, кроме того,

кто и «сам обманываться рад», ими любовались

и иногда играли. Они показывали возможность

человеческого творчества и сознания создавать

иную реальность, пусть и воображаемую [11, с. 9].

Исследования вторжения технологий в современный художественный процесс порождают все новые дискурсы в изучении даже хорошо известных художественных явлений. Особый интерес вызывает роль цифровых технологий в таких синтетических формах искусства, как музейные и выставочные инсталляции, где с появлением реди-мейдов электронные и цифровые устройства выступают как в качестве самостоятельных арт-объектов, так и носителей художественного контента, невидимых источников аудиовизуального и светового содержания экспозиций.

Выдвинутая в качестве одной из тем дискуссий рубрика «Мнимые экранные объекты» проявила новую оптику изучения творчества известного своими масштабными музейными проектами московского художника Александра Райхштейна (1957 г.р.), более 30 лет живущего в Хельсинки и активно работающего в России и Северной Европе. Будучи по образованию художником книги, А. Райхштейн начинал творческий путь как иллюстратор художественной литературы и художественный редактор издательства «Искусство». Переехав по семейным обстоятельствам в Финляндию, уже известный в профессиональной среде художник столкнулся с необходимостью освоения компьютерных технологий, овладев которыми в начале 90-х в Университете промышленных искусств в Хельсинки (сейчас университет Аалто), продолжил заниматься искусством книги.

Однако новое социокультурное пространство способствовало диверсификации творческих устремлений Райхштейна. Столкнувшись с финскими традициями партиципаторных практик в пространстве доступной музейной среды, нацеленной на массового, в том числе детского (0+) и семейного посетителя, он создает перформативные инсталляции, где детская энергия оказывается пусковым механизмом и движущей силой, трансформирующей художественные формы. Триггерами для погружения профанного посетителя в иммерсивное пространство становятся зрительные, тактильные или слуховые иллюзии. Часто созданные при помощи новейших материалов или технических средств «обманки» наполняют выставочное пространство атмосферой сказочного волшебства, создавая эмоциональный фон для восприятия многоуровневого информационного контента, посвященного истории культуры, художественному наследию, современным проблемам общества или природы.

Одним из первых проектов Райхштейна, воплощенных благодаря цифровым технологиям, стала инсталляция «Гнездо» (2007), созданная для анималистической выставки «Время животных» в музее Атенеум (Хельсинки) в качестве ее детского отдела. В основе концепции выставки была выбрана идея предложить ребенку, пришедшему на экспозицию, примерить на себя роль птенца, щенка или маленького животного, для чего ему предоставлялась возможность забраться в настоящее, пусть и гигантское гнездо, выполненное из стволов молодых рябин и мягкого войлока. В гнезде дети оказывались рядом с невидимым беспомощным существом, находящимся в огромном яйце и задающим вопросы о мире, в котором он должен вскоре оказаться. Реагируя на внешнее воздействие, арт-объект, встраиваясь в многочисленные коммуникации, умело варьировал вопросы на трех языках, вскрикивая и пугаясь, услышав в ответах, что посетители ели на завтрак яичницу. Студенты Александра расписали стены зала, изобразив гигантские растения и насекомых, дополнив иллюзию восприятия крошечного обитателя огромного и опасного мира. Сама экспозиция, включающая в себя пришедших на выставку посетителей с детьми, приобретала характеристики живой скульптуры.

Примером выставки, концептуально основанной на зрительских иллюзиях, стала тотальная выставочная инсталляция «Пабло и Александр. Игры с Пикассо» (2009), приуроченная к выставочному турне коллекции Музея Пикассо в Париже. На экспозиции зритель оказывался перед монументальной копией картины П. Пикассо «Читающая» (1953), а затем, приближаясь к изображению, обнаруживал, что поверхности картины не существует, оказываясь перед пространством глубиной четыре метра. Следуя подсказке «Войди в картину», 


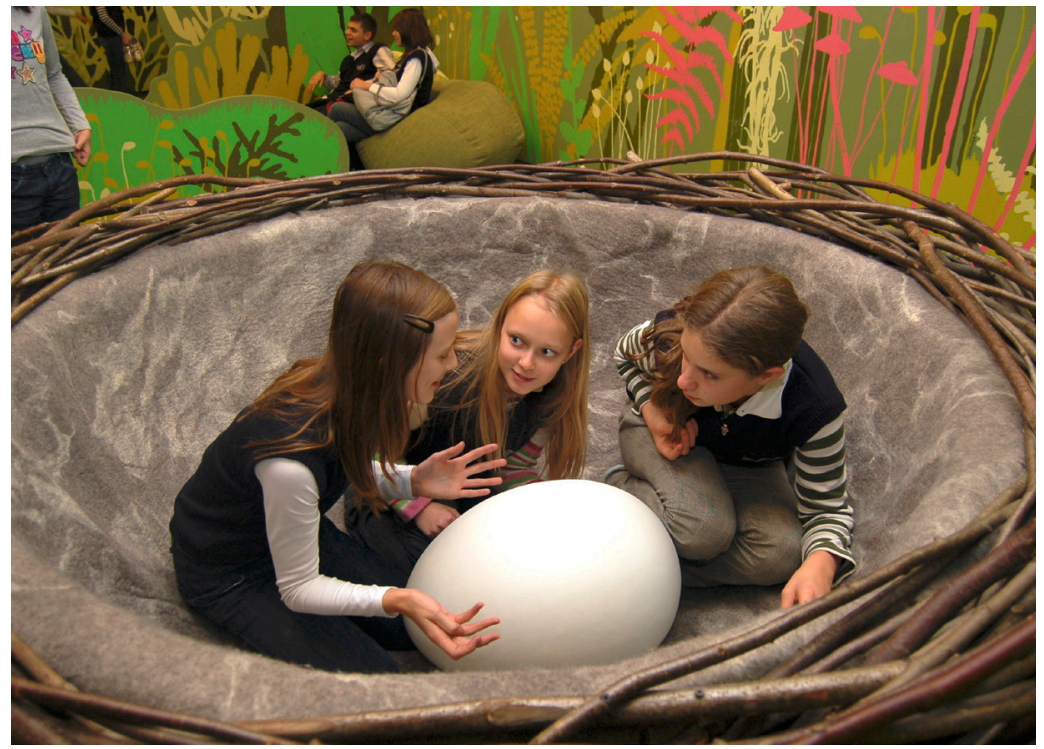

Ил. 6. Александр Райхштейн, фрагмент инсталляции «Гнездо». Хельсинки, Атенеум, 2007

публика, перешагивая через золотую раму, попадала в пространство инсталляции, плотно наполненное аудиовизуальным контентом, посвященным творчеству П. Пикассо. В лабиринтах из балконов и лестниц аутентичная техника 1950-х годов выполняла роль гиперссылок экспозиционного текста, транслируя документальный фильм «Тайны Пикассо» А.-Ж. Клузо на экране и голос самого художника в старинной трубке телефонного аппарата. Для тех же, кто оставался снаружи рамы, посетители превращались в персонажей картины, иллюстрируя высказывание Пикассо о том, что жизнь произведения искусства начинается с момента представления его зрителю.

В серии инсталляций, выполненных в рамках музеефикации руинированного пространства Гатчинского дворца, цифровые технологии выполняют функции «машины времени», вовлекая публику в разнообразные коммуникации с дворцовыми обитателями прошлых эпох и перемещая ее в пространстве истории повседневности нескольких поколений. При этом каналы коммуникаций варьировались достаточно широко.

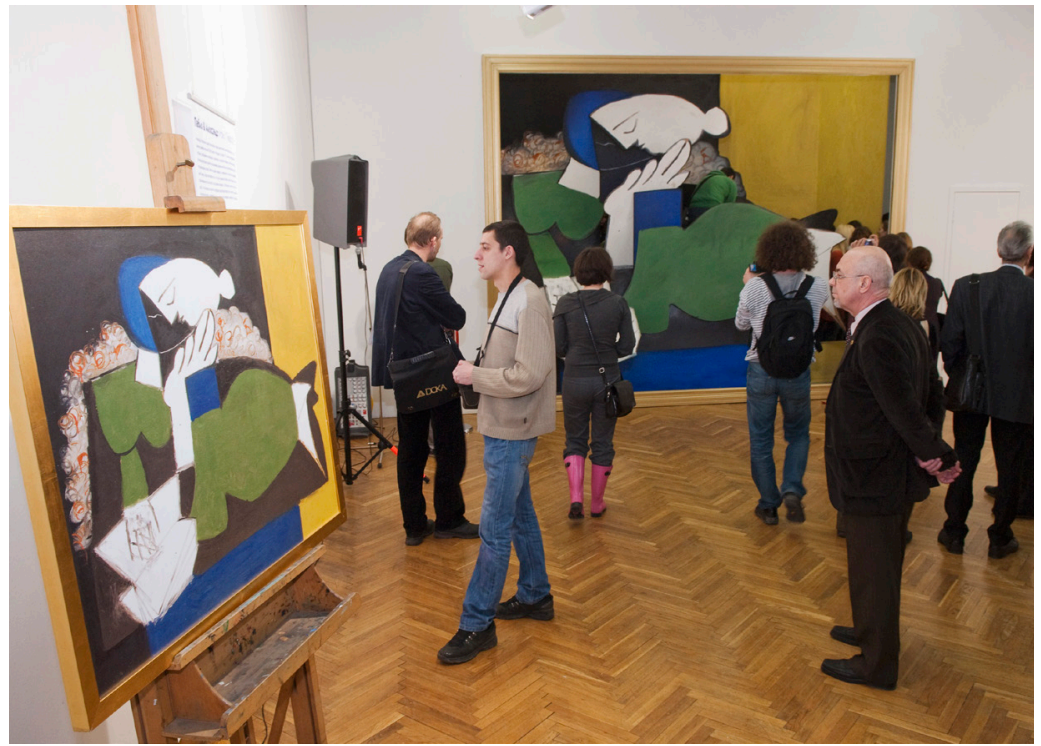

Ил. 7. Александр Райхштейн. Инсталляция «Пабло и Александр. Игры с Пикассо». Санкт-Петербург, Экспозиционно-выставочный комплекс «Вселенная воды», 2010

Так, в аудиоинсталляции «Звучащая площадь» (2011), созданной в рамках фестиваля фонда Про Арте «Современное искусство в традиционном музее», воплощена идея параллельных миров, где современная публика, оказываясь перед дворцом, одновременно вовлекается в жизнь прошедших эпох. Детально реконструированное звуковое пространство утренних военных парадов Павла I вызывает иллюзию присутствия на старинном военном плацу среди жителей предыдущих столетий. Точно спроецированные на территории площади звуки, как оказалось, заставляют прохожих двигаться в строгом марше под барабанную дробь, уклоняться от невидимой скачущей лошади, вздрагивать от возгласа вестового, выкриков военных команд самого императора, пугаться пушечных выстрелов и всматриваться в небо, заслышав карканье взлетающих ворон.

Образы видеоинсталляции «Шествие теней» (2015), напоминающие ожившие тени персонажей силуэтных открыток прошлых веков, возникают перед публикой, переходящей из музейных залов Гатчинского дворца в пространство руин. Под пронизанное исторически- 
ми реминисценциями музыкальное повествование 5-й симфонии Д. Шостаковича на уцелевшей мраморной стене дворца шествуют придворные и царские особы, проплывают силуэты фрейлин, семенят с колясками служанки, мчатся на велосипедах и игрушечных лошадках по дворцовым коридорам дети и левретки, чеканя шаг, под звук фанфар маршируют приближающиеся тени революционных матросов. Острое впечатление от присутствия прячущихся за пилястрами светящихся в темноте силуэтов достигалось средствами видеомаппинга на мраморной лестнице Гатчинского дворца и оставалось одним из самых сильных впечатлений туристов.

Победителем конкурса «Золотой Трезини» был признан реализованный в 2018 году проект реставрации и консервации Чесменской галереи Гатчинского дворца, разработанный А. Райхштейном. По мнению художника, «руина производит не меньшее, а порой и более сильное впечатление, чем отреставрированный интерьер дворца». Автором было предложено законсервировать галерею в ее сохранности на момент начала реставрации и отреставрировать лишь один из повторяющихся раппортов архитектурного убранства интерьера, состоящего из окна с портьерами, позолоченного лепного орнамента, наборного паркета и вмонтированного в стену живописного полотна. Пусковым механизмом художественной коммуникации со зрителем в этом случае оказывается проявляющаяся на своем историческом месте утраченная живописная копия полотна Я.Ф. Хаккерта, посвященного Чесменскому сражению, в сопровождении реконструированного грохота морского боя.

Аудиовизуальный маппинг также использован художником в экологическом проекте, посвященном исчезающим видам животных, «Последний парад», демонстрируемом на международных фестивалях света в Москве, Лондоне, Торуни и Леувардене. В качестве сюжета Райхштейн использует знакомый по анималистическим картинам и рассказам сюжет водопоя, примиряющего хищников и их жертв. По задумке художника, на водопой, как и на Ноев Ковчег, звери приходят попарно, но не для спасения и расселения по всей планете, а чтобы сделать последний глоток и исчезнуть с лица земли навсегда. Выполненные в натуральную величину силуэты животных шествуют вдоль кромки воды, отражаясь в ее поверхности. Издавая рычанье и рев, изображения исчезают под стоны и рычание подражающих им детей и угрызенья совести взрослых, наблюдающих трагические последствия людской безответственности.

Как считает Александр Райхштейн, благодаря современным возможностям цифровых технологий «ты вступаешь в контакт с существами прошлых времен, что возможно только на спиритических сеансах или даже с теми, кто еще не родился». На теоретическом уровне эту тенденцию подчеркивал в своем последнем труде Я.Б. Иоскевич: «Новые технологические возможности не вытесняют старых, но наличие новых - материальных и процессуальных - составляющих творчества постоянно меняет его алгоритмы. Для сегодняшнего состояния культуры в целом и художественной в частности характерно все более активное вторжение коммуникативных составляющих» [5, с. 71].

Гуркина Н.С.

\section{«Машинный век» в американском искусстве. 1918-1941}

Период между двумя мировыми войнами в США был осознан как «машинный век». «Дух и буква» американского индустриального и урбанистического ландшафта, бурно развивавшегося в эти годы, породили сложный комплекс умонастроений, связанный с активным вторжением человека в мир природы, размыванием патриархальных ценностей бытия пуританской глубинной Америки, появлением нового игрока в экзистенциальном поле человека - машины. Мосты и дамбы, фабрики и элеваторы, железнодорожные пути и водонапорные башни означали окончательное покорение дикой Природы, превращение аграрной по преимуществу страны в индустриальную и урбанизированную. Аэропланы, пароходы, поезда, автомобили наглядно и ощутимо воплощали мощь, энергию, скорость. Все это не только видоизменяло американский ландшафт и бытовую среду, но и проникало в качестве объекта изображения в живопись и графику, скульптуру и фотографию, дизайн и архитектуру. Новая реальность порождала и новые, иногда полярные настроения в обществе по отношению к машине как неотъемлемому отныне компоненту жизни человека: оптимизм, энтузиазм, романтизацию, обожествление, поклонение, одержимость, беспокойство, тревожность. Поднимались вопросы о сосуществовании машины и человека, социальные ожида- 
ния варьировались от улучшения качества жизни, комфорта, экономического роста до зависимости, подчинения, непредсказуемости, замещения. В искусстве появляется запрос на изображение энергично развивающейся Америки («American Scene»), поиск соответствующего формального словаря, создание новой национальной художественной идиомы - машины как факта и как символа современной эпохи. В 1920-е годы оптимизм американцев предкризисной поры отождествлял фабрики с соборами и церквями (Ч. Демут. «Фимиам новой церкви», 1921).

Стилистические признаки американского искусства «машинного века» на первоначальном этапе демонстрируют влияние европейского авангарда в США 1913-1920-х годов: кубизм, футуризм, реди-мейд, дадаизм (М. Дюшан, М. Рэй, Ф. Пикабиа). Мортон Л. Шамберг первый обратился к новым «машинным мотивам» («Механическая абстракция», «Скважина», 1916), впрочем американцам оказалась близка не столько игра, ирония, провокация, эпатаж будущих дадаистов, сколько обретение свободы обращения с предметом, смелое обобщение и преодоление иллюзорности изображения, абстрагирование, но до определенных пределов. Сведение образа к знаку, внедрение в предмет и разложение его на элементы несут отголоски кубизма и дадаизма в картине Джеральда Мерфи «Часы» (1925).

Первая попытка аналитического обзора современного состояния в архитектуре, инженерно-промышленном и изобразительном искусстве была предпринята в рамках международной выставки The Machine Age (1927, Нью-Йорк). Оформление обложки каталога декоративной композицией работы Ф. Леже с центральным элементом в виде стилизованного шарикоподшипника задавало тон содержанию и проблематике: машина как элемент цивилизации и культуры XX века. Л. Лозовик в статье «Американизация искусства» указывает на доминирующие тренды времени: «путь индустриализации и стандартизации требует от художника объективности, исключающей эмоциональные аберрации и обращающей его видение к формам и цветам, не имеющим параллелей в Природе... Потребность к порядку и организации выражается в строгой геометрии американского города: вертикалях дымовых труб, параллелях автомобильных трасс, квадратах городских планировок, кубах фа- брик, арках мостов, цилиндров газовых цистерн...» [8, с. 150-152]. Таким образом, задача художника - схватить и запечатлеть эти ритмы и образы современной Америки, красноречиво воплотив национальную идиому.

Мысли, высказанные Л. Лозовиком, как нельзя лучше будут воплощены в 1920-1930-х годах в художественном течении прецизионизм (термин выдвинут А. Барром в 1927 году) - утопическом мире индустриальных ландшафтов и механизмов, созданных при помощи пуристической точности формально-композиционных выразительных приемов. Облик промышленной Америки - главная тема лидера прецизионизма Ч. Шилера. В цикле художественных фотографий и картин на их основе он обнажает абстрагированную красоту чистых геометрических линий и масс мощных сооружений, являя новый «пантеизм машинного XX века». Изображение крупным планом машинного оборудования на палубе большого океанского лайнера «Маджестик» («Верхняя палуба», 1927) дает представление о методе художника: опираясь на фотографию, достигнуть точного соответствия ей в картине, избегая выраженной живописности, но и не впадая в мелочный натурализм. По заказу журнала Fortune в 1939 году им была написана серия картин на тему промышленных достижений Америки - механизмов, осуществляющих силу движения, вращения, паровой и водяной энергии («Мощность вращения», «Подвешенная сила. Водяная турбина», «Паровая турбина»).

В 1920-е годы машинные мотивы проникают и в декоративноприкладное искусство. Так, симбиоз элегантного стиля ар-деко с машинной эстетикой воплощен в оформлении входа в офис в Чанин-билдинг, Нью-Йорк (1928). Скульптор Рене П. Чамбелан совмещает геометризм зигзагообразных «молний» в декоре стальной с медными элементами решетки со стилизованными зубцами, зубчатыми колесиками, шестеренками, гаечками, заполняющими сквозные боковые створки и центр композиции.

В 1930-х новая стилистика под названием streamline - «линия обтекания», происходящим от термина из области аэродинамики, проникает в практику дизайнеров Н.Б. Геддеса, Р.Ф. Лоуи, Г. Дрейфуса. Предметы промышленного дизайна - от настольных ламп до моделей поездов и автомашин - отличаются преобладанием горизонталей, обтекаемых силуэтов, динамичностью форм, общей тенденцией 


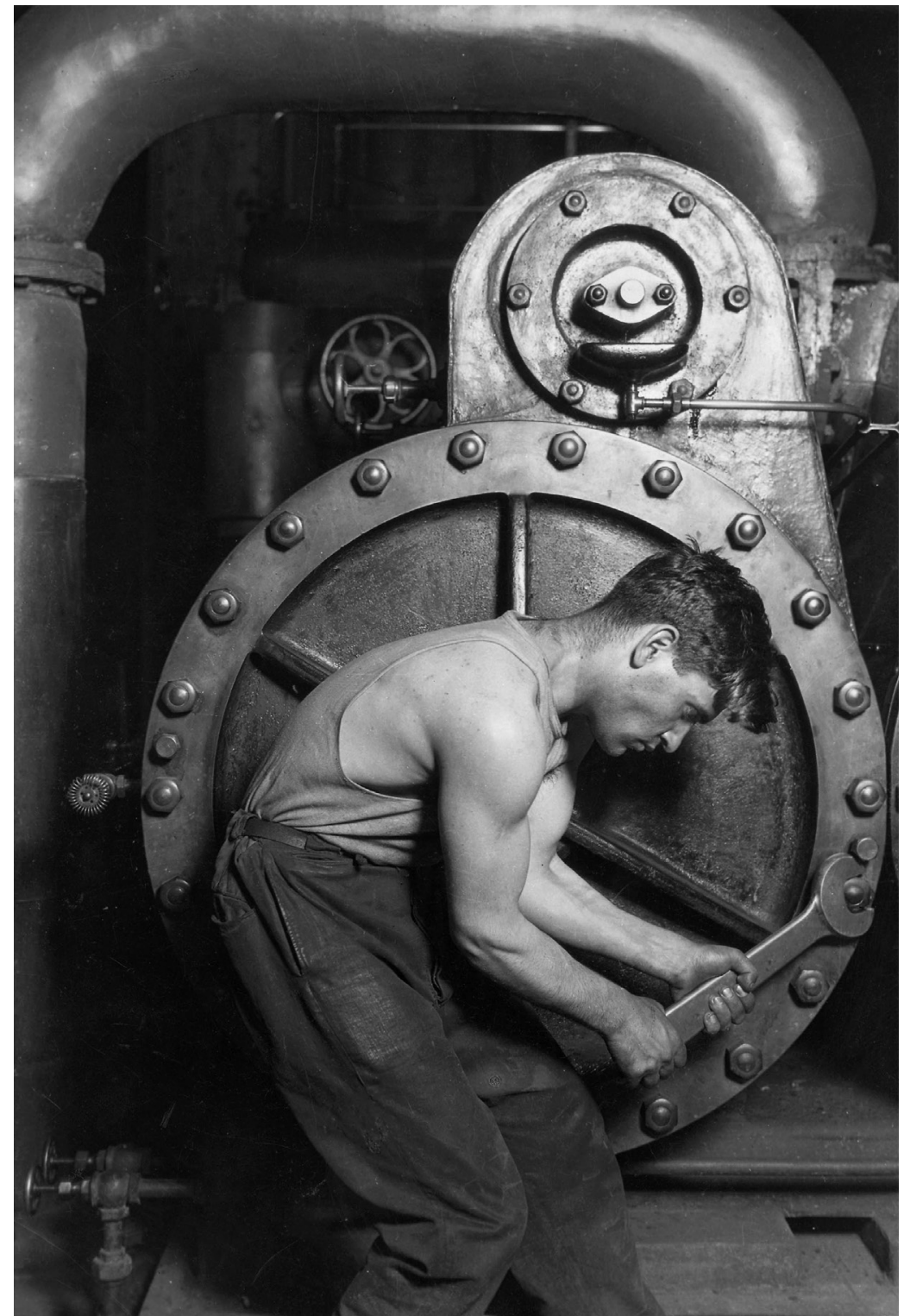

Ил. 8. Льюис Хайн. Рабочий и паровой насос. Фотография. 1920 / Mechanic and Steam Pump. J. Paul Getty Museum, Los Angeles, USA // bridgemanimages.com к простоте и эргономичности. В этом стиле дизайнер Раймонд Лоуи спроектировал, например, футуристическую точилку для карандашей (1934), чья каплевидная обтекаемая форма стала стилеобразующей для промышленного дизайна на многие годы вперед.

В области промышленного дизайна «машинный век» требовал не только поиска новой эстетики, но и включения машины в процесс изготовления предметов потребления, использования новых материалов, технологий. Выставка Machine Art (1934) в Музее современного искусства в Нью-Йорке продемонстрировала красоту и полезность потребительских товаров (от кофеварок до аэропланов), произведенных машинным способом по разработкам дизайнеров, задавая ориентиры для формирования художественных вкусов в самых разных областях современного дизайна. На обложку каталога Д. Альберсом было вынесено изображение «Самоустанавливающегося шарикоподшипника», представленного здесь в виде монументального символа механики и технической мысли. Параллелью этому мотиву служит фотография Льюиса Хайна «Рабочий и паровой насос» (1920), где композиция строится на повторяющихся плавных линиях, заданных наклонным движением молодого рабочего и круглых элементов огромного механизма, чья круговая ритмика подчеркнута множеством гаек, требующих усилия гаечного ключа. Причем фигура рабочего на равных соотносится с механистической частью, а не подчинена ей. Хайну принадлежит и знаменитая серия фотографий рабочих-высотников на строительстве Эмпайр-стейт-билдинг в моменты работы и отдыха на фоне металлических конструкций (1930-1931).

В 1920-1930-х годах художники, дизайнеры, коммерсанты, общество в целом пытались осознать, понять, принять и, наконец, взять под контроль мир, управляемый машиной. В этот период американцы развили собственную эстетику, связанную с машиной, в изобразительном искусстве и дизайне. После Второй мировой войны наступает эра открытия новых энергий - атомной, ядерной. Механические машины уступают место «думающим машинам», машинный век сменяется веком компьютерных технологий. 
Казючиц М.Ф.

\section{Образы науки и техники в документальном полиэкранном кино}

\section{США 1950-1960 годов}

Период после Второй мировой войны, в особенности десятилетия конца 1940-х - 1960-х годов, характеризуется динамичным развитием документального кинематографа, в ряде случаев тесно связанного с экспериментальным и научно-популярным кино (в отечественной литературе подобный эклектизм был зафиксирован в виде термина «художественно-публицистический фильм»). При этом развитие происходит в рамках не только кинотеатральных показов, но и телевидения. В свою очередь, документальное/научно-популярное кино реализуется, помимо стандартных киносеансов (киножурналы или самостоятельные фильмы), в рамках кинозрелища/киноаттракциона ${ }^{(1)}$.

Популярность подобных технологий обусловливалась культурноисторической ситуацией. В послевоенном мире начинают активно развиваться новые виды промышленности (атомная, космическая, высокие технологии - компьютерные системы), усиливается консолидация стран, входящих в соответствующие политические кластеры периода холодной войны. В этом контексте тема науки и техники выступает основой для риторики международной колларборации и мирного сотрудничества.

Наибольшую популярность как за рубежом, так и в СССР приобретает полиэкранное кино (это условное название, включающее разные варианты демонстрации таких кинопроекций - вариоско-

Полиэкранные фильмы могли иметь самостоятельное эстетическое значение и выступать в качестве кинозрелища. Примером подобных самостоятельных полиэкранных (или вариополикадровых) проектов являются фильмы группы «Совполикадр» на Мосфильме («Наш марш», «Интернационал» и др.). Полиэкранные (вариополикадровые) проекты, особенно в США, начиная с 1960-х годов активно включались в высокобюджетные кинофильмы («Гран-при»; «Афера Томаса Крауна» и др.) в качестве самостоятельных эпизодов.

В рамках Экспо полиэкранные (вариополикадровые) фильмы могли также нередко являться элементом киноаттракциона - высокобюджетной инсталляции, включавшей строительство специального пространства (павильона), конструирование зала

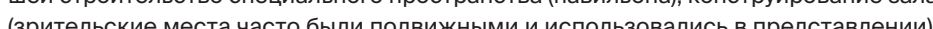

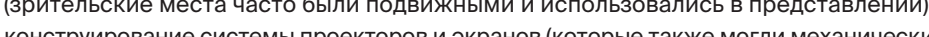
трансформироваться в процессе демонстрации). См. подробнее [15]. пия, поликадр, вариополикадр), которое стало компромиссом между задачами массового кинозрелища/киноаттракциона [15, с. 132-165], документального и научно-популярного кино. Своего пика полиэкранное кино за рубежом (США, Канада и др.) и в СССР достигает в 1950-1960-е годы. Эти десятилетия известны бурным развитием кинопромышленности, внедрением инновационных технологий. В отечественной литературе они известны как «новые кинотеатральные системы» (полиэкран, кинопанорама, широкоформатное кино, кругорама и др.). При различных особенностях производства и проката в отдельных странах полиэкранное кино используется, прежде всего, на международных выставках Экспо, где занимает место кинозрелища/киноаттракциона, реализующего одновременно задачи документального и научно-популярного кино.

Значительный интерес представляет опыт США в комбинировании различных форматов и видов кино (документальное, анимация и др.) для популяризации науки с применением полиэкранных фильмов. Американская документалистика достигает больших успехов уже в период Второй мировой войны в качестве кинопропаганды, где активно применялись сложные комбинированные техники, после войны способствовавшие значительному обогащению выразительных возможностей документального кино [6].

Так, в полиэкранном фильме «Здание науки» (House of Science, реж. Ч. Имс, Р. Имс), представленном на Экспо в Сиэтле в США в 1962 году, вполне ясно отражен сложный характер связи науки и социума. Тема фильма - зарождение и последующее развитие науки - представляется в виде метафоры - города, в котором появляются все новые и новые здания-отрасли и инфраструктура становится все более дифференцированной.

Технология демонстрации фильма - классический полиэкран: проекция из шести отдельных экранов и проекторов. Показательно, что образы науки и техники занимают ключевое место: представлены адресными планами крупных ученых с мировым именем; различных научных приборов, аппаратных комплексов, зданий ведущих научных центров и т.д.

Интернациональные кинопроекты, отражающие коллаборацию между западным и восточным блоками в разгар холодной войны, несмотря на их сравнительно небольшое число, представляют осо- 
бый интерес. Основа мирных отношений, например между СССР и США, в те годы нередко представлена в документальном, научнопопулярном кино через образы науки и техники. Примером такого полиэкранного фильма может служить картина «Образы США» (Glimpses of the U.S.A., реж. Ч. Имс, Р. Имс), подготовленная для Американской национальной выставки 1959 года в Москве [23, p. 192-200]. Фильм начинался с закадрового голоса комментатора: «Когда мы смотрим на ночное небо, мы видим звезды... Они одинаково далеки как от американских городов, так и от русских городов...». После тезиса о природе, единой для всех, вводится основной блок с урбанистическими, помимо машинных, образами: автомобили (салон изнутри, отдельные модели, плотные потоки транспорта с высоты птичьего полета); дорожные развязки (вид с самолета); адресные панорамные планы городов (Нью-Йорк, Сан-Франциско и др.); затем высотные здания (здания целиком, фрагменты, здания вместе с несколькими домами). Образы техногенной цивилизации использовались в фильме с различными целями: во-первых, популяризация, культурные связи (знакомство советских зрителей с жизнью Америки); во-вторых, кинопропаганда, демонстрация высочайшего экономического, технологического потенциала (и фактического превосходства) США как мировой державы. Этим, вероятно, объясняется малый объем экранного времени, отведенного для людей и природы: технократические образы являются доминирующими.

Начиная с 1960-х годов все более активно развивается компьютерная промышленность, в частности хорошо известны различные промопроекты компании IBM на международных Экспо. Попытка репрезентации человеческого разума как компьютера с целью популяризации ЭВМ (и продукции IBM, разумеется), повышения доверия к ним сделана в полиэкранном фильме «Думать» (Think, реж. Ч. Имс, Р. Имс, 1964) [23, p. 248-258], демонстрируемого в рамках киноаттракциона «Стена людей» (People Wall) в павильоне IBM, выполненном в форме сфероида (архитектор Э. Сааринен). На сцене размещались девять экранов различных форматов, проекция создавалась четырнадцатью проекторами, также в представлении принимал участие живой исполнитель-конферансье. Экраны располагались в горизонтальной плоскости, верхние и боковые экраны образовывали «захлесты» в зал по аналогии с экраном классической кинопанорамы. Ведущий резю-

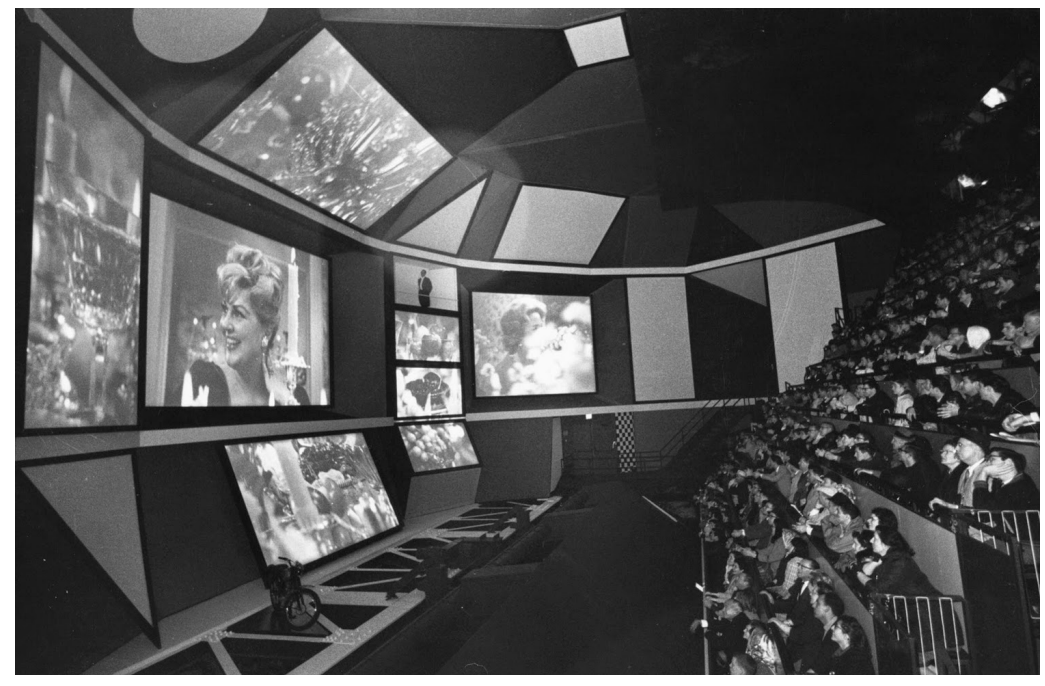

Ил. 9. Полиэкранная композиция. Киноаттракцион «Стена людей» (People Wall). Павильон IBM

мировал в финале: «...Компьютеры программируются для того, чтобы обрабатывать информацию и устанавливать связи, но ведь это просто более сложный способ использовать всем нам знакомые принципы, к которым мы прибегаем ежедневно». На простых примерах в фильме проводилась прямая аналогия между работой человеческого разума и ЭВМ (редукция комплексной проблемы к простой, формализация, моделирование и пр.), а сам аттракцион де-факто предлагал зрелище: наблюдение за мышлением человека.

Таким образом, сама концепция международных Экспо, особенно в послевоенные годы, связывалась с демонстрацией технологических достижений различных государств, поэтому вполне естественно, что образы науки и техники представлялись, как правило, в сциентистском ключе и являлись центральными. Вместе с тем наука и наукократический послевоенный мир представляется универсальной коммуникационной средой, способной объединить человечество силой просвещенного наукой и технологиями разума. Последнее обстоятельство, то есть всеобщий характер такого месседжа, принципиально: полиэкранные документальные/научно-популярные фильмы рассчитывались на максимально широкую аудиторию. 
Образы машинной цивилизации, таким образом, включают не только сугубо сциентистские, наукократические элементы (научные приборы и аппаратные комплексы, объекты космической, атомной, электронной промышленности), но и неразрывно связанные с ними урбанистические образы (объекты инфраструктуры городов). Подобный эклектизм образов для 1950-1960-х годов, репрезентирующий, вероятно, потенцию всякого государства-участника Экспо (во всех его аспектах) для игры на поле нового послевоенного мира, становится неотъемлемым элементом идеологии.

Образы машинной цивилизации, по крайней мере на уровне формы (композиции, монтажа, выбора темы) полиэкранных фильмов, приобретают экуменистический характер: компьютеры, наукоемкие технологии представлены как естественное, эволюционное продолжение биологической природы самого человека и его познавательной способности. Показателен финал фильма «Здание науки»: слова диктора о «человеке науки», «способном и жаждущем постичь своим умом и воображением мир вокруг себя», перекрыты кадрами человеческого лица и капли воды на листе растения.

Вирен Д.Г.

\section{Техника в польском кино эпохи «реального социализма»}

Вполне очевидно, что разного рода технические устройства появлялись на социалистическом киноэкране и в 1950-е, и в 1960-е годы, порой становясь маркером определенного социального статуса. В первую очередь это касается автомобилей, что было с горькой иронией обыграно, например, в запрещенном фильме Ежи Сколимовского «Руки вверх» (Ręce do góry, 1967/1981). Однако в 1970-е меняется и количество, и качество представленной в кинолентах техники, что непосредственно связано с социально-политическими изменениями.

В 1970 году первым секретарем ЦК ПОРП стал Эдвард Герек, его правление уложилось ровно в одно десятилетие. После общественных потрясений рубежа 1960-1970-х (студенческие волнения и антисемитская кампания 1968 года, кроваво подавленные протесты рабочих на Побережье в 1970 году) был взят курс на улучшение общественного благосостояния. Эту эпоху называют «реальным социализмом» или даже «второй оттепелью». Несмотря на то что внешне жизнь действительно становилась более благополучной, государственные долги углубляли экономический кризис, а протестные настроения усиливались и привели к возникновению «Солидарности».

Первая половина 1970-х прошла под знаком стремления к обогащению при сохранении социалистической идеологии. Излишняя увлеченность ценными вещами была чревата мещанством, которое осуждалось официально, но именно тогда все сильнее стала ощущаться оторванность лозунгов от реальной жизни. Критик и культуролог Кшиштоф Теодор Теплиц в известной книге «Обитатели коллективного воображения», вышедшей на заре эпохи Герека, отмечал: «...такие символы, как автомобиль, хорошая квартира и оснащенность предметами роскоши, несомненно, сохранили свою ценность. Кажется даже, что их значение увеличивается по мере общего обогащения социума и укрепления общественной стабилизации. Образ общества потребителей, к которому мы приближаемся в плане показателей валового национального дохода, не кажется большинству наших граждан морально отталкивающим» [27, s. 59-60].

Констатируя формирование в социалистической стране общества потребления, мы неизбежно сталкиваемся в этот период со множеством противоречий, порождаемых изменившейся ситуацией. В польском кинематографе 1970-х эти проблемы нашли яркое отражение. Так, в картине Витольда Лещиньского и Анджея Костенко «Личный досмотр» (Rewizja osobista, 1973), которую исследовательница Юстына Яворская в своем оригинальном труде [25] причисляет к «кино польского соцконсумпционизма», все действие происходит в пункте таможенного досмотра на границе. Герои возвращаются с абстрактного Запада на машине, до отказа заполненной одеждой, косметикой, бытовыми предметами, что, естественно, вызывает вопросы у пограничников. Двусмысленная игра, которую персонажи ведут между собой, завершается поджогом машины, осуществленным юным сыном главной героини. Таким образом показано как противопоставление двух миров - социалистического и западного, так и своеобразная контестация вещизма и потребления как такового.

1970-е - это также период бурного строительства и индустриального развития. В документально-постановочном фильме Войчеха Вишневского «Ванда Гостиминьская, ткачиха» (Wanda Gościmińska, 


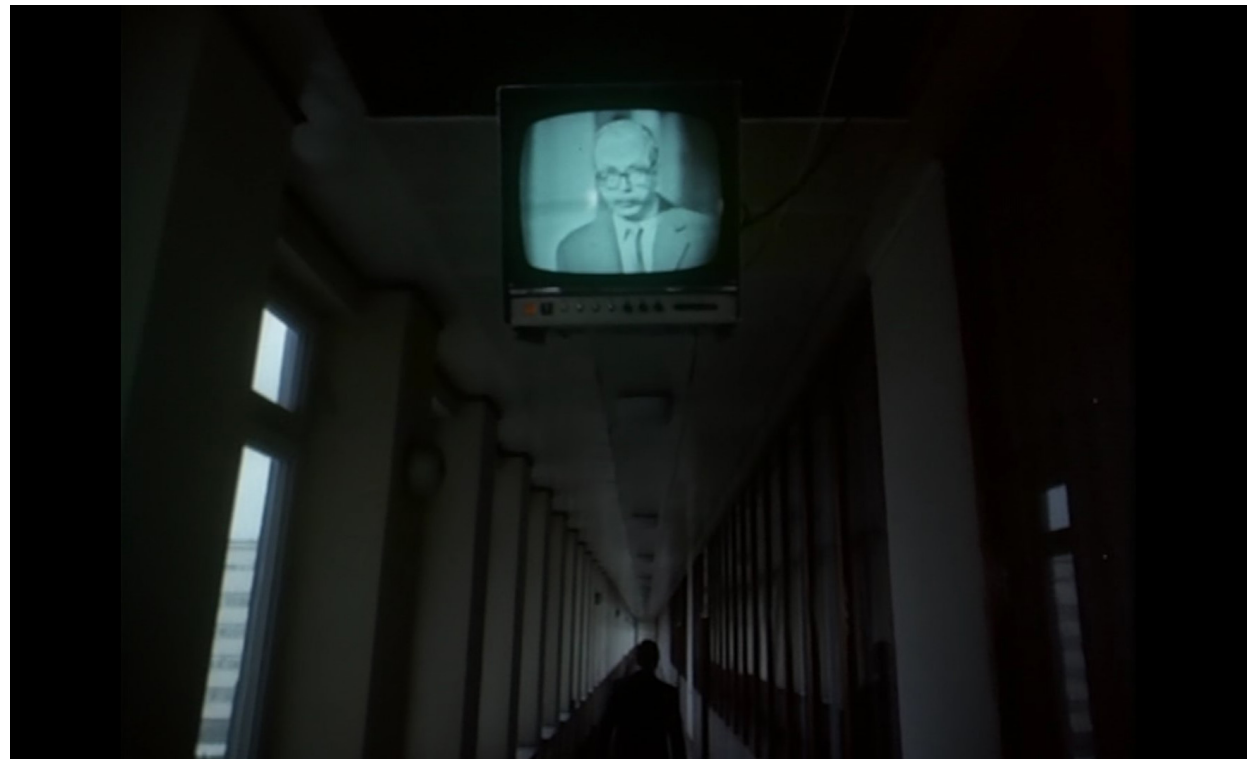

Ил. 10. Кадр из фильма «Танцующий ястреб» (Tańczący jastrząb), режиссер Гжегож Круликевич, 1977

włókniarka, 1975) есть эпизод с символическим названием «Сегодня». В нем демонстрируется цех с современными текстильными станками, а главная героиня восторженно повествует о достижениях социализма в сравнении с довоенной безработицей и нищетой. Но и тут есть оборотная сторона - «расчеловечивание» ударника труда. Гостиминьская становится неким живым роботом, машиной, для которой первоочередной задачей является выполнение плана.

Оппозиция прогресса и природы, общественного и индивидуального обостряется к концу десятилетия. Художники рассуждают о готовности людей к бурной урбанизации страны, выводят на первый план проблему слома традиционного жизненного уклада, столкновения городского и деревенского образов жизни. В дебютной полнометражной ленте Кшиштофа Кесьлевского «Шрам» (Blizna, 1976), формально - производственной драме, рассказана история строительства комбината, ради которого необходимо вырубить лес и расселить частные дома, что вызывает протесты. Необходимость поиска компромисса между потребностью в развитии региона и гуманным отношением к мест- ным жителям явлена в образе рефлексирующего директора Беднажа (Франчишек Печка). Любопытно, что решение оставить пост он принимает, прослушав свое интервью, записанное в самом начале работы на культовый магнитофон «Награ», созданный в Швейцарии инженером польского происхождения. «Вы знаете, что „Награ“ - лучший магнитофон в мире?» - задумчиво спрашивает он у журналиста.

Похожий конфликт, но с более драматичными последствиями, выведен в «Танцующем ястребе» (Tańczący jastrząb, 1977) Гжегожа Круликевича - экранизации одноименной повести Юлиана Кавалеца. Далеко не последнюю роль в повествовании о блестящей карьере Михала Топорного играют технические устройства. Особенно выделяются вездесущие мониторы, установленные в коридорах и кабинетах предприятия. Сами по себе они довольно непривычны для середины 1970-х. Судя по всему, при их помощи осуществляется видеонаблюдение, однако изображение на этих экранах не совпадает с «реальностью». Так усугубляется ощущение раздвоенности главного героя, который всеми силами пытается соответствовать своему новому образу энергичного начальника, в глубине души оставаясь «к земле приписанным» (цитируя название другого произведения Кавалеца). Мониторы в «Танцующем ястребе» носят немного зловещий характер, равно как и телефоны, которые постоянно акцентируются в кадре, навевая ассоциации с прослушкой, ставшей в те годы злободневной темой на Западе.

Неоднозначность доступности технических новинок раскрывается в «Кинолюбителе» (Amator, 1979) Кесьлевского. Если в «Шраме» было показано увлечение героя фотографией, то Филип Мош (Ежи Штур) обыкновенный рабочий - приобретает советскую любительскую камеру для того, чтобы снимать ребенка. События, однако, приобретают неожиданный оборот: становясь своего рода хроникером жизни завода, Мош сталкивается с лицемерием, двойными стандартами и в конечном счете самой настоящей цензурой.

Техническое средство как образ частной творческой инициативы, стремления молодого человека к независимости возникает в «Высоком полете» (Wysokie loty, 1978) - весьма одиозной картине Рышарда Филипского, представляющей, по определению Тадеуша Любельского, «кино партийного контрнаступления» [26, s. 414-415], реакции на «кинематограф морального беспокойства». Самолет, самостоятельно сконструированный героем картины в собственной квартире, ока- 
зывается камнем преткновения, символом противостояния честных граждан и прогнивших чиновников либерального толка.

Наконец, «Бусинки одних четок» (Paciorki jednego różańca, 1980) Казимежа Куца в известном смысле подытоживают наши размышления. Здесь вновь выстроена оппозиция деревни и города: на смену традиционной модели существования приходит урбанистическая. И хотя в новом доме пожилого шахтера есть все, о чем только мог мечтать поляк в начале 1970-х (телевизор, радио, холодильник, утюг), это не приносит ему счастья. Образы техники используются в польском кинематографе 1970-х годов в разных контекстах и с разным смыслом. Демонстрируя повышение благосостояния, они в то же время способны провоцировать конфликты и выявлять не очевидные ранее проблемы.

\section{Смолев Д.Д.}

\section{«Объективный» взгляд машины}

Пытаясь описать взгляд робота на экране, зрители справедливо оперируют набором голливудских клише. Как правило, речь идет о кадрах, снятых субъективной камерой, движение которой подчеркнуто автоматизировано и сопровождается механистичными звуками (скажем, джойстика). Кадр тонирован в едкий цвет, а по экрану скачут цифры, диаграммы и показатели, назначение которых не всегда понятно.

Сегодня подобная репрезентация машинного зрения кажется типичной, однако в сознании массового зрителя она сложилась лишь в 1980-1990-е годы, когда персональные компьютеры (ПК) наводнили рынки, а в прокат вышли первые фильмы крупнобюджетных технофобных франшиз - «Терминатор» (The Terminator, реж. Дж. Кэмерон, 1984), «Робокоп» (RoboCop, реж. П. Верховен, 1987) и др.

Впрочем, самих роботов люди увидели на экране значительно раньше, чем роботы «увидели людей». Поначалу их зрение попросту не подлежало имитации. Фантастические миры населяли либо неодушевленные конструкции, которые члены съемочной группы неустанно передвигали по площадке, либо загримированные артисты, облаченные в не слишком удобные костюмы. Первая заметная

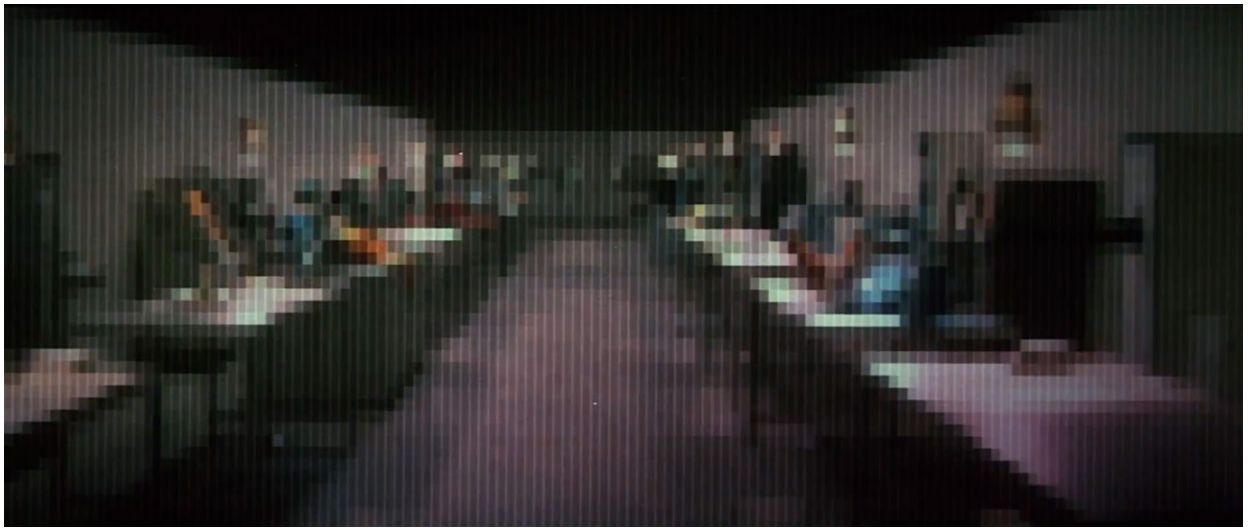

Ил. 11. Кадр из фильма «Мир Дикого Запада» (Westworld), режиссер Майкл Крайтон, 1973

попытка реконструировать (фактически - вообразить) зрение машины предпринял в 1968 году Стэнли Кубрик в фильме «2001 год: Космическая одиссея» (2001: A Space Odyssey). Взгляд самообучаемого компьютера HAL 9000 не содержал какие бы то ни было цифры или схемы, кадр не был тонирован, а единственным указанием на «робозрение» стал использованный оператором Джеффри Ансуортом широкоугольный объектив («рыбий глаз»).

Стоит отметить, что в отрыве от контекста предложенный Кубриком ракурс мог бы принадлежать любому субъекту, отличному от человека, - животному, божеству и др. Это визуальное решение не предполагало и намека на то, как машина мыслит, чувствует, что она умеет и как воспринимает окружающее пространство. Всю эту информацию аудитории фильма предлагалось собрать из повествовательных поворотов и диалогов; изображение на этот счет безмолвствовало.

Заговорило же оно спустя пять лет в картине «Мир Дикого Запада» (Westworld, реж. М. Крайтон, 1973), посвященной противостоянию людей и вышедших из-под контроля андроидов, главный из которых носил прозвище Стрелок (Юл Бриннер). Чтобы передать холодный взгляд машины, режиссер Майкл Крайтон и пионер CGI-технологий Джон Уитни-младший покадрово отсканировали сцены, снятые от лица героя, оцифровали, пикселизировали на компьютере, а затем вернули на пленку для дальнейшего монтажа. Примечательно, что 
похожую процедуру «перевода» с человеческого языка на цифровой и обратно проходили в те же годы фотоснимки поверхности Марса, сделанные НАСА в рамках космической программы «Маринер». Они и вдохновили Уитни на смелый эксперимент.

Так первое компьютеризированное (цифровое) зрение машины в истории кино создала сама машина, в сущности, оставив отпечатки несуществующих пальцев - сделав своеобразное селфи. В дальнейшем этот «марсианский ген» будет неосознанно нести в своем ви́дении каждый робот и киборг мирового экрана, а оппозиции «живого мертвого», «разумного - неразумного» мифологизируются на новой технологической почве, составив магистральный конфликт и контекст непростых взаимоотношений человека и машины.

Чем можно объяснить их обострившуюся в последние десятилетия XX века сложность? Как известно, 1970-е годы оказались в США временем глобальных параной и ознаменовались тотальным кризисом доверия как к власти (рефлексия Вьетнамской войны, Уотергейт и др.), так и к тем технологиям, с которыми она ассоциировалась. В результате на глазах «умневшие» компьютеры, с одной стороны, представляли собой верных и надежных помощников, а с другой, контролировали пуск (не-запуск) ядерных боеголовок. Само допущение, что металлический объект вдруг превратится в металлический субъект с собственной волей и разумом, вполне естественно повергало обывателей (да и не только их) в ужас, рождая сильнейшую неопределенность: робот - он свой или все-таки чужой?

Визуальное отражение этой конфронтации можно найти практически в любом фильме 1980-1990-х годов, где продемонстрирована точка зрения робота. Например, в культовом «Робокопе» Пола Верховена примечательна сцена рождения киборга. Зритель наблюдает настройку его операционной системы как процесс, который на момент премьеры был хорошо знаком большинству американцев по собственным компьютерам. То же узнавание случается и при виде горизонтальных полос на мониторе - исключительно компьютерного артефакта, возникающего при неисправности в матрице или при наведении на экран камеры.

Но почему в голливудских фильмах машины смотрят на мир так же (или почти так же), как люди смотрят на них? Фактически зритель присутствует при рождении новой условности: переносе нашего ви́дения машин на зрение самих машин, коим те - как органом чувств - не обладают.

Впрочем, элементарной «адаптацией зрачков» дело не ограничилось. Одновременно с ней на ярко окрашенные экраны выводились таинственные данные и графики, которые не просто не развивали нарратив, а являлись бессмысленными с точки зрения своего функционала («Газонокосильщик» (The Lawnmower Man, реж. Б. Леонард, 1992), «Эвольвер» (Evolver, реж. М. Росман, 1995), «Двухсотлетний человек» (Bicentennial Man, реж. К. Коламбус, 1999), «Терминатор-3: Восстание машин» (Terminator 3: Rise of the Machines, реж. Дж. Мостоу, 2003), «Я, робот» (I, Robot, реж. А. Пройас, 2004) и многие другие). В большинстве случаев зритель попросту не успевает разобрать, что же ему показывают - кадр длится секунду и даже меньше. Или шрифты, которыми были набраны бегущие цифры, казались настолько мелкими, что вновь лишали аудиторию самой возможности проникнуть в машинное сознание.

С одной стороны, это кунштюк и хитрость - заведомый обман зрителя, которому под видом многозначительной абракадабры предлагается ничто. С другой, сама методика обмана семантична: она указывает на несовершенство человека по сравнению с экранным роботом, ведь чтобы уличить авторов фильма в манипуляции, требуется поставить фильм на паузу, перемотать, укрупнить изображение - то есть прибегнуть к помощи все той же машины. Но явленная ущербность зрителя не считывалась аудиторией как недостаток (зрителя и фильма) - она подчеркивала аутентичность роботизированного зрения, превращая его в вещь в себе.

Вероятно, субъективный взгляд робота на мир, созданный Голливудом в последние десятилетия XX века, представлял собой точку встречи человека и машины, узнаваемого и чужого, знакомого и незнакомого. Этот визуальный консенсус позволил авторам фильмов начать длительный процесс гуманизации роботов, вылившийся к 2010-м годам если не в слом, то в реформацию сложившихся визуальных штампов.

Например, в сериале «Мир Дикого Запада» (Westworld, с 2016 года), созданном по мотивам одноименного фильма Майкла Крайтона, шоураннеры Джонатан Нолан и Лиза Джой отказались от пикселизированного зрения машины. В их интерпретации точка ви́дения 
робота абсолютно неотличима от человеческой, и одна эта деталь превращает андроидов не просто в полноправных акторов сериала, а в угнетенную социальную группу, что поднимает целый спектр актуальных проблем: от расовой и гендерной дискриминации до возрождения фашизма в невинных на первый взгляд формах.

\section{Заключение}

Во второй половине XX века Бенуа Мандельброт до основания сотряс мир, опубликовав свое открытие, названное им «Фрактальная геометрия природы» (1977). Сложный код, достоверно применимый к математически точному определению береговой линии, горного хребта, спустя годы вдохновил создателей фильмов «Матрица», которые в свою очередь запустили в оборот киноискусства новые векторы конфликта человека и машины. Е.В. Сальникова обнаружила прообразы актуальных и востребованных современностью технологий «облака» (хранилища) и полиэкранных форм композиции в эпических произведениях Гомера - «Илиаде» и «Одиссее» [12].

Сегодня сохраняется устойчивая тенденция не только к синтезу искусств, но и миграции технических приемов, уловок, оборудования. Зачастую они воплощаются в использовании экранных устройств в сценических, выставочных пространствах, а в сфере киноискусства это могут быть полиэкранные композиции кадра, различные визуальные приемы и глубинно-философские вопросы, поднимаемые персонажами и даже самой киноматерией. Круг произведений и области применения машинной цивилизации не ограничиваются киноискусством, созданием и репрезентацией произведений искусства в музеях, включением экранных панелей в цирковое и театральное пространство, но и востребованы в сфере компьютерных игр, технический и эстетический уровень которых возрастает с каждым годом. Например, как своеобразную анатомию широчайшего спектра конфликтов машинного и человеческого можно охарактеризовать компьютерную игру «Детройт: стать человеком» (Detroit: Become Human, 2018, Quantic Dream, Sony Interactive Entertainment).

К.Б. Соколов сделал важный вывод, что «техническое начало неустанно приводит к возникновению новых явлений, предметов, принципов коммуникации и бытования культуры - и если новизна очень уж сильна и экстраординарна, то ее оказывается сложно бесконфликтно признать одной из форм существования человека» [14, с. 567]. Однако в процессе самоидентификации, очерчивания границ истинно человеческого и машинного, образы машин обрастают бесчисленным количеством интерпретаций, могут выступать темой, приемом, контекстом, декорацией, персонажем. Техника и технологии могут конфликтовать с человечеством, бороться за его выживание и процветание и даже пытаться идентифицировать себя в мире людей. 


\section{Список литературы:}

1 Бескова И.А., Князева Е.Н., Бескова Д.А. Природа и образы телесности. М.: ПрогрессТрадиция, 2011. $456 \mathrm{c}$.

2 Богомолова Д.А. Социальная сеть ТikTok как элемент интегрированных маркетинговых коммуникаций // Вопросы студенческой науки. 2020. № 4 (44). С. 572-576.

3 Дуков Е.В. Социально-культурные проблемы Сети // Наука телевидения. 2013. № 10 С. $97-108$.

4 Зелезинская Л.А., Чупров А.С. Проданный смех // Социум и власть. 2013. № 6 (44). С. 103-106.

5 Иоскевич Я.Б. Новые пространства и форматы художественно-эстетической деятельности в культуре рубежа нового тысячелетия. СПб.: РИИИ, 2019. 294 с.

6 Казючиц М.Ф. Американское документальное кино и анимация как средства решения пропагандистских задач в период II Мировой войны // Международный журнал исследований культуры. 2020. № 4 (41) С. 52-68.

7 Козинцев А.Г. Компьютерные программы- шутники и теория юмора // Серия «Московский лингвистический журнал». 2009. № 11. С. 215-227.

8 Лозовик Л. Американизация искусства // Вестник иностранной литературы. 1928. № 1. С. 150-152.

9 Мерло-Понти М. Феноменология восприятия / Пер. с фр. И.С. Вдовиной, С.Л. Фокина. СПб: Наука, Ювента, Gallimard, 1999. 602 с.

10 Ницше Ф. Человеческое, слишком человеческое: книга для свободных умов. М.: Академический проект, 2007. 328 с.

11 Пиотровский М.Б. «Сам обманываться рад» // «Не верь глазам своим». Обманки в искусстве. СПб.: Изд-во Государственного Эрмитажа, 2018. 504 с.

12 Сальникова Е.В. Предыстория волшебства экранов. Мотивы «Илиады» и «Одиссеи» // Наука телевидения. 2018. № 14.1. С. 120-157.

13 Семенова Е.А. Карнавализация: научное понятие и живая реальность // Проблема хронотопа в современных научных исследованиях: Международный круглый стол, посвященный М.М. Бахтину (Москва, 19-20 апреля 2017 года): Сборник докладов и статей. М.: ФГБНУ «ИХОИК РАО», 2017. С. 315-332.

14 Соколов К.Б., Сиюхова А.М., Дворник Ф.С., Быканова Е.В., Спутницкая Н.Ю., Гуров О.Н. Феномен технологического. Гуманитарные аспекты // Художественная культура. 2021. № 3. C. 564-599. https://doi.org/10.51678/2226-0072-2021-3-564-599.

15 Тарасенко Л.Г., Чекалин Д.Г. Кинозрелища и киноаттракционы: справочник. М.: Науч.-исслед. КИнофотоинститут (НИКФИ); ПАРАДИЗ, 2003. 184 с

16 Трауберг Л. Мир наизнанку: социально-критические мотивы в американской кинокомической 1910-1930-х годов / Послесл. С. Юткевича. М.: Искусство, 1983. 301 с

17 Траусан-Мату С. Влияние идей Бахтина на обработку естественного языка, электронное обучение и развитие творчества // Наследие М.М. Бахтина: культура - наука образование - творчество. Международный круглый стол, посвященный М.М. Бахтину (22 мая 2018 года, Орел). Сборник докладов и статей / ред.-сост., пер. Е.А. Семенова. М.: ИХОик 2018 C. 417-425.
18 Тульчинский Г.Л. Человек-машина и машина-человек в искусстве: встреча в цифре // Художественная культура. 2021. № 3. С. 112-127. https://doi.org/10.51678/2226-0072-2021-3$112-127$.

19 Урри Дж. Социология за пределами обществ. Виды мобильности для XXI столетия. М.: Высшая школа экономики, 2012. С. 64.

20 Эвалльё В.Д. Экранная среда в пространстве московского метрополитена // Вестник славянских культур. 2021. Т. 60. С. 8-20. https://doi.org/10.37816/2073-9567-2021-60-8-20.

21 Эвалльё В.Д., Крутоус В.П. «Гуманизация» искусства: музеи в интернет-среде // Художественная культура. 2021. № 1. С. 222-243. https://doi.org/10.51678/2226-0072-2021-1222-243.

22 Brodesco A. TikTok come incubo // Nazione Indiana. 2019. 17 Giugno. URL: https://www. nazioneindiana.com/2019/06/17/tik-tok-come-incubo/ (дата обращения 17.09.2021).

23 Eames C., Eames R. An Eames Anthology: Articles, Film Scripts, Interviews, Letters, Notes, and Speeches / Ostroff D. (Ed.). New Haven, Connecticut: Yale University Press, 2015. 420 p.

24 Hoelzl I. Screens - The Place of the Image in Digital Culture // Digital Continuities. From the History of Digital Art to Contemporary Transmedial Practices / ed. by N. Lambert, E. Edmond // Transactions. Leonardo. Journal of the International Society for the Arts, Sciences, and Technology. 2012. Vol. 45. №. 5. Pp. 474-475.

25 Jaworska J. «Piękne widoki, panowie, stąd macie». O kinie polskiego sockonsumpcjonizmu. Kraków: Universitas, 2019. $324 \mathrm{~s}$.

26 Lubelski T. Historia kina polskiego. Twórcy, filmy, konteksty. Katowice: Videograf II, 2009. $624 \mathrm{~s}$.

27 Toeplitz K.T. Mieszkańcy masowej wyobraźni. Warszawa: Państwowy Instytut Wydawniczy, 1972. $209 \mathrm{~s}$.

28 Zahoor A. Linguistic Humor in Memes to Mitigate Post Covid-19 // Severity, Linguistics and Literature Review. 2020. No. 6 (2). Pp. 11-23. 


\section{References:}

1 Beskova I.A., Knyazeva E.N., Beskova D.A. Priroda i obrazy telesnosti [Nature and Images of Corporeality]. Moscow, Progress-Tradiciya Publ., 2011. 456 p. (In Russian)

2 Bogomolova D.A. Social'naya set' TikTok kak element integrirovannyh marketingovyh kommunikacij [Social Network TikTok as an Element of Integrated Marketing Communications]. Voprosy studencheskoj nauki, 2020, no. 4 (44), pp. 572-576. (In Russian)

3 Dukov E.V. Social'no-kul'turnye problemy Seti [Socio-Cultural Problems of the Network]. Nauka televideniya [The Art and Science of Television], 2013, no. 10, pp. 97-108. (In Russian)

4 Zelezinskaya L.A., Chuprov A.S. Prodannyj smekh [Sold Laughter]. Socium i vlast', 2013, no. 6 (44), pp.103-106. (In Russian)

5 loskevich Ya.B. Novye prostranstva i formaty hudozhestvenno-esteticheskoj deyatel'nosti v kul'ture rubezha novogo tysyacheletiya [New Spaces and Formats of Artistic and Aesthetic Activity in the Culture of the Turn of the New Millennium]. St. Petersburg, RIII Publ., 2019. 294 p. (In Russian)

6 Kazyuchic M.F. Amerikanskoe dokumental'noe kino i animaciya kak sredstva resheniya propagandistskih zadach v period II Mirovoj vojny [American Documentary Films and Animation as a Means of Solving Propaganda Problems During World War II]. Mezhdunarodnyj zhurnal issledovanij kul'tury, 2020, no. 4 (41), pp. 52-68. (In Russian)

7 Kozincev A.G. Komp'yuternye programmy shutniki i teoriya yumora [Computer Joker-Programs and the Theory of Humor]. Moskovskij lingvisticheskij zhurnal, 2009, no. 11, pp. 215-227. (In Russian)

8 Lozovik L. Amerikanizaciya iskusstva [Americanization of Art]. Vestnik inostrannoj literatury, 1928, no. 1, pp. 150-152. (In Russian)

9 Merlo-Ponti M. Fenomenologiya vospriyatiya [Phenomenology of Perception], translated by I.S. Vdovina, S.L. Fokin. St. Petersburg, Nauka Publ., Yuventa Publ., Gallimard Publ., 1999. 602 p. (In Russian)

10 Nietzsche F. Chelovecheskoe, slishkom chelovecheskoe: Kniga dlya svobodnyh umov [Human, Too Human: A Book for Free Minds]. Moscow, Akademicheskij Proekt Publ., 2007. 328 p. (In Russian)

11 Piotrovskii M.B. "Sam obmanyvat'sya rad" ["I Am Glad to Be Deceived"]. "Ne ver' glazam svoim". Obmanki v iskusstve ["Do not Believe Your Eyes". Deceptions in Art]. St. Petersburg, Izd-vo Gosudarstvennogo Ermitazha Publ., 2018. 504 p. (In Russian)

12 Salnikova E.V. Predystoriya volshebstva ekranov. Motivy "lliady" i "Odissei" [The Prehistory of the Magic of Screens. Motives from the "Illiad" and the "Odyssey"]. Nauka televideniya [The Art and Science of Television], 2018, no. 14.1, pp. 120-157. (In Russian)

13 Semenova E.A. Karnavalizaciya: nauchnoe ponyatie i zhivaya real'nost' [Carnivalization: Scientific Concept and Living Reality]. Problema hronotopa v sovremennyh nauchnyh iss/edovaniyah: Mezhdunarodnyj kruglyj stol, posvyashchennyj M. M. Bahtinu (Moskva, 19-20 aprelya 2017 goda): Sbornik dokladov i statej [Chronotope Problem in Modern Scientific Research: International Round Table Dedicated to M.M. Bakhtin (Moscow, April 19-20, 2017): Collection of Reports and Articles]. Moscow, FGBNU “IHOiK RAO” Publ., 2017, pp. 315-332. (In Russian)

14 Sokolov K.B., Siyuhova A.M., Dvornik F.S., Bykanova E.V., Sputnickaya N. Yu., Gurov O.N. Fenomen tekhnologicheskogo. Gumanitarnye aspekty [A Technological Phenomenon. Humanitarian Aspects]. Hudozhestvennaya kul'tura [Art \& Culture Studies], 2021, no. 3, pp. 564-599. https://do org/10.51678/2226-0072-2021-3-564-599. (In Russian)
15 Tarasenko L.G., Chekalin D.G. Kinozrelishcha i kinoattrakciony: spravochnik [Film Shows and Cinema Attractions: a Reference Book]. Moscow, Nauch-issled. kinototoinstitut (NIKFI) Publ. PARADIZ Publ., 2003. 184 p. (In Russian)

16 Trauberg L. Mir naiznanku: Social'no-kriticheskie motivy vamerikanskoj kinokomicheskoj 19101930-h godov [The World Inside Out: Socio-Critical Motives in American Kinocomic 1910-1930s], afterword by S. Yutkevich. Moscow, Iskusstvo Publ., 1983. 301 p. (In Russian)

17 Trausan-Matu S. Vliyanie idej Bahtina na obrabotku estestvennogo yazyka, elektronnoe obuchenie i razvitie tvorchestva [Influence of Bakhtin's Ideas on the Processing of Natural Language, Electronic Learning and the Development of Creativity]. Nasledie M.M. Bahtina: kul'tura - nauka obrazovanie - tvorchestvo. Mezhdunarodnyj kruglyj stol, posvyashchennyj M.M. Bahtinu (22 maya 2018 goda, Orel): sbornik dokladov i statej [The Legacy of M.M. Bakhtin: Culture - Science Education - Creativity. International Round Table Dedicated to M.M. Bakhtin (May 22, 2018, Orel): Collection of Reports and Articles], ed, translator E.A. Semenova. Moscow, IHOiK Publ 2018 pp. 417-425. (In Russian)

18 Tulchinskii G.L. Chelovek-mashina i mashina-chelovek v iskusstve: vstrecha v cifre [Man-Machine and Machine-Man in Art: Meeting in Digital]. Hudozhestvennaya kul'tura [Art \& Culture Studies] 2021, no. 3, pp. 112-127. https://doi.org/10.51678/2226-0072-2021-3-112-127. (In Russian)

19 Urri Dzh. Sociologiya za predelami obshchestv. Vidy mobil'nosti dlya XXI stoletiya [Sociology Publ., 2012. 336 p. (In Russian)

20 Evallyo V.D. Ekrannaya sreda v prostranstve moskovskogo metropolitena [Screen Environment in the Moscow Subway (Metro)]. Vestnik slavianskikh kul'tur, 2021, vol. 60, pp. 8-20. https://doi. org/10.37816/2073-9567-2021-60-8-20. (In Russian)

21 Evallyo V.D., Krutous V.P. "Gumanizaciya" iskusstva: muzei v internet-srede ["Humanization" of Art: Museums on the Internet]. Hudozhestvennaya kul'tura [Art \& Culture Studies], 2021, no. 1, pp. 222-243. https://doi.org/10.51678/2226-0072-2021-1-222-243. (In Russian)

22 Brodesco A. TikTok come incubo. Nazione Indiana, 2019, 17 Giugno. Available at: https://www. nazioneindiana.com/2019/06/17/tik-tok-come-incubo/ (accessed 17.09.2021)

23 Eames C., Eames R. An Eames Anthology: Articles, Film Scripts, Interviews, Letters, Notes, and Speeches, Ostroff D. (Ed.). New Haven, Connecticut, Yale University Press, 2015. 420 p.

24 Hoelzl I. Screens - The Place of the Image in Digital Culture // Digital Continuities. From the History of Digital Art to Contemporary Transmedial Practices / ed. by N. Lambert, E. Edmonds // Transactions. Leonardo. Journal of the International Society for the Arts, Sciences, and Technology, 2012, vol. 45, no. 5, pp. 474-475.

25 Jaworska J. "Piękne widoki, panowie, stąd macie”. O kinie polskiego sockonsumpcjonizmu. Kraków, Universitas, 2019. $324 \mathrm{~s}$.

26 Lubelski T. Historia kina polskiego. Twórcy, filmy, konteksty. Katowice, Videograf II, 2009. 624 s.

27 Toeplitz K.T. Mieszkańcy masowej wyobraźni. Warszawa, Państwowy Instytut Wydawniczy, 1972. 209

28 Zahoor A. Linguistic Humor in Memes to Mitigate Post Covid-19. Severity, Linguistics and Literature Review, 2020, no. 6 (2), pp. 11-23. 